\title{
Peran Sosial Finance Baitul Maal Wat Tamwil (BMT) dalam Menumbuhkan Keuangan Inklusif: Studi pada BMT di Tulungagung dan Blitar
}

\author{
Lantip Susilowati \\ Fakultas Ekonomi dan Bisnis Islam IAIN Tulungagung \\ Email:lantip_susilowati@yahoo.co.id
}

\begin{abstract}
:
Baitul Maal wat Tamwil aims to manage business and social affairs that have not been maximized. This is indicated by the distribution of charity social funds. Based on these problems, this paper intends to explore how the implementation and role of BMT social finance in growing financial inclusion ?. The method used is a qualitative type and descriptive approach. The results of this paper are the first, Implementation of social finance management of social finance fund sources and distribution of social finance funds. Sources of social finance funds in the form of zakat, infaq, social funds, and distribution of social finance in the form of social assistance, scholarships, and qardul hasan financing. Second, the role of Baitul Maal wat Tamwil Pahlawan Tulungagung's social finance role in fostering financial inclusion, among others in the form of Qardh al-Hasan financing and other direct assistance. The role of social finance in growing financial inclusion in the BMT Podo Joyo Blitar includes in the form of Qardh al-Hasan financing and assistance for orphans in the form of savings accounts and assistance for widows.

[Baitul Maal wat Tamwil bertujuan mengelola bisnis dan social yang belum maksimal. Hal itu terindikasi adanya penyaluran dana sosial yang bersifat charity. Berdasarkan masalah tersebut, paper ini bermaksud mendalami bagaimana implementasi dan peran social finance BMT dalam menumbuhkan keuangan inklusif?. Metode yang digunakan adalah jenis kualitatif dan pendekatan deskriptif. Hasil dari paper ini adalah pertama, Implementasi social finance pengelolaan sumber dana social finance dan distribusi dana social finance. Sumber dana social finance berupa zakat, infaq, dana sosial, dan distribusi social finance berupa bantuan sosial, beasiswa, dan pembiayaan qardul hasan. Kedua, Peran social finance Baitul Maal wat Tamwil Pahlawan Tulungagung dalam menumbuhkan keuangan inklusif antara lain dalam bentuk pembiayaan Qardh al-Hasan dan bantuan lainnya bersifat langsung. Peran social finance dalam menumbuhkan keuangan inklusif pada BMT Podo Joyo Blitar antara lain dalam bentuk pembiayaan Qardh al-Hasan dan bantuan untuk yatim dalam bentuk akun tabungan serta bantuan untuk janda.]
\end{abstract}

Kata Kunci: Social finance, Baitul Maal wat Tamwil, Keuangan inklusif. 


\section{PENDAHULUAN}

BMT sebagai lembaga keuangan berbeda dengan konvensional, yaitu mengeluarkan dana sosialnya dalam bentuk zakat. Paper Romdhoni,1 menyebutkan bahwa Terdapat pengaruh positif antarapendayagunaan program zakat produktif LAZ An-Naafi" Boyolali terhadap pendapatan mustahiq. Bahwa pendapatan mustahiq dipengaruhi oleh pendayagunaan zakat produktif dengan besar sumbangan pengaruh adalah 30,5\%. Jika BMT mengeluarkan zakatnya yang disalurkan kepada masyarakat kurang mampu, maka harapannya akan meningkatkan pendapatan masyarakat. Nah dalam hal ini harapannya masyarakat akan menyisihkan sebagian pendapatannya pada BMT sebagai bentuk tabungan. Artinya jika zakat sebagai variabel sosial dilaksanakan oleh BMT, maka akan meningkatkan peluang masyarakat mengakses BMT dalam bentuk simpanan. Kondisi demikian menurut Damanhur dan Nurainiah, ${ }^{2}$ bahwa zakat berpengaruh terhadap kesejahteraan masyarakat di Kabupaten Aceh Utara, dimana besar pengaruhnya sebesar 57\%. Jika BMT memfungsikan zakat sebagai variabel sosial keuangan, maka BMT berkontribusi dalam mempengaruhi kesejahteraan masyarakat.

Menjadi tantangan bagi pengembangan keuangan sosial dalam Islam, Martowardoyo ${ }^{3}$ menyebutkan bahwa lembaga keuangan sosial dalam Islam antara lain Lembaga keuangan mikro, wakaf dan nirlaba, menjadi satu optimistis dan memiliki potensi yang menjanjikan untuk kesejahteraan masyarakat. ${ }^{4}$ Lembaga keuangan mikro inilah yang menjadi sasaran dalam penelitian ini sehingga diharapkan mampu menjawab sejauhmana peran social finance BMT dalam menumbuhkan keuangan inklusif di masyarakat. Menurut Nugroho dan Purwanti, ${ }^{5}$ bahwa determinan inklusi keuangan di Indonesia adalah tingkat pendapatan, tingkat pendidikan, dan usia. Social finance pada keuangan syariah berpotensi untuk di kembangkan menurut Bashori ${ }^{6}$ antara lain pengelolaan ziswaf (zakat, infaq dan wakaf), keuangan syariah dalam pengentasan kemiskinan, keuangan sosial syariah, serta integrasi keuangan komersial dan sosial syariah.Terkait hal tersebut, paper ini akan mendiskusikan perihal bagaimana implementasi social finance pada Baitul Maal wat Tamwil di Tulungagung dan Blitar? Dan bagaimana peran social finance Baitul Maal wat Tamwil dalam menumbuhkan keuangan inklusif?

Kondisi ini menurut Perhimpunan Baitul Mal wat Tamwil Indonesia (PBMTI), diperlukan upaya memfokuskan untuk bertahan dengan memberikan pembinaan pada para anggota. Menurut Ketua Umum Perhimpunan Baitul Mal wa Tamwil Indonesia (PBMTI) Joelarso mengatakan, penyebab tertekannya bisnis BMT disebabkan banyaknya pesaing

\footnotetext{
${ }^{1}$ Abdul Haris Romdhoni, "Zakat Dalam Mendorong Pertumbuhan Ekonomi Dan Pengentasan Kemiskinan," Jurnal Ilmiah Ekonomi Islam 03, no. 01 (2017): 41-51.

${ }^{2}$ Damanhur and Nurainiah, "Analisis Pengaruh Bantuan Zakat Terhadap Tingkat Kesejahteraan Masyarakat Kabupaten Aceh Utara," Jurnal Visioner \& Strategis 5, no. 2 (2016): 71-82.

${ }^{3}$ Agus D.W. Martowardojo, "Integrating Islamic Commercial and Social Finance to Strengthen Financial System Stability," International Seminar and the 2nd JIMD (2016): 1-8.

${ }^{4}$ Fadlan Fadlan, "KONSEP PEMBANGUNAN EKONOMI BERBASIS ISLAM (Sebuah Upaya Pembangunan Ekonomi Indonesia yang Adil, Makmur, dan Sejahtera)," Al-Ihkam: Jurnal Hukum \& Pranata Sosial 5, no. 2 (2012): 257-274.

${ }^{5}$ Ari Nugroho and Evi Yulia Purwanti, Determinan Inklusi Keuangan Di Indonesia (Semarang, 2014).

${ }^{6} \mathrm{M}$ Anwar Bashori, Mendorong Pengembangan Islamic Social Finance Dalam Rangkat Mewujudkan Masyarakat Sejahtera, Bank Indonesia (Indonesia, 2017).

18
} 
besar yang merusak karakter pelaku mikro. ${ }^{7}$ Lembaga keuangan yang bukan mikro atau perbankan yang akses funding dan financing-nya masuk wilayah mikro menyebabkan pelaku mikro mendapatkan pembiayaan / kredit dari banyak lembaga, bisa sampai 5 atau 6 lembaga. Kebijakan pemerintah dengan memberikan peluang bagi Perbankan untuk mengelola program mensubsidi bunga Kredit Usaha Rakyat (KUR) menyebabkan pasar BMT kepada anggota menjadi terganggu. BMT dalam rangka sustainabilitas, efisiensi biaya, maka margin yang ditetapkan melebihi standard KUR karena BMT tidak mendapat alokasi sumber dana murah dari negara.

\section{METODE PENELITIAN}

Pendekatan yang digunakan adalah pendekatan kualitatif dengan melakukan pengamatan, wawancara atau penelaahan dokumen. Teknik analisis data yang digunakan dalam penelitian adalah data yang bersifat kualitatif dengan metode deskriptif. Metode tersebut dilakukan dengan Model analisis interaktif terhadap komponen pengumpulan data dari berbagai siklus yaitu mulai dari mereduksi data yang diperoleh dari lapangan, menyajikan data dalam bentuk tabel yang mudah dimengerti, dan melakukan penarikan kesimpulan.

\section{HASIL DAN PEMBAHASAN}

\section{Hasil implementasi Social Finance pada BMT Pahlawan Tulungagung dan BMT Podo Joyo Blitar}

\section{Zakat}

BMT Pahlawan Tulungagung memiliki kebijakan mengeluarkan zakat lembaga pada tiap bulannya. ${ }^{8}$ Zakat yang dikeluarkan oleh BMT Pahlawan Tulungagung sebesar Rp.111.458.227 (Seratus sebelas juta empat ratus lima puluh delapan ribu dua ratus dua puluh tujuh rupiah) pada tahun 2017 dan 105.269.776 rupiah pada tahun 2018. Pada tahun tersebut zakat yang kosong pada bulan Oktober 2018, namun demikian pada bulan berikutnya zakat yang dikeluarkan sebesar 18.174.060 rupiah, tumbuh 99,07 persen dibanding bulan sebelumnya pada tahun $2017 .{ }^{9}$

Pertumbuhan zakat tertinggi pada bulan Nopember 2018, dimana pertumbuhannya mencapai 99,07 persen. Sedangkan pertumbuhan terendah pada bulan sebelumnya, yaitu Oktober 2018. Pada bulan tersebut, BMT tidak mengeluarkan zakat. Secara umum, zakat yang disalurkan oleh BMT tahun 2018 mengalami penurunan sebesar 5,55\% dibanding tahun 2017. Menurut Rokhman, bahwa "zakat yang disalurkan BMT adalah 2,5\% dari pendapatan BMT. Jika pendapatan BMT turun, maka zakat BMT juga ikut turun". 10

Zakat tersebut dikelola sendiri oleh BMT dalam wadah Baitul Maal yang dimiliki. Penyaluran zakat yang dilakukan BMT menurut direktur utama BMT Pahlawan sudah atas

\footnotetext{
${ }^{7}$ Asep Sudrajat, Bisnis tertekan, BMT siapkan strategi Bertahan di tahun 2017, diakses melalui http://republika.co.id/berita/ekonomi/syariah-ekonomi/17/02/01/oknz4c383-bisnis-tertekan-bmtsiapkan-strategi-bertahan-di-2017.

8 Nyadin, Direktur Utama BMT Pahlawan Tulungagung, Konfirmasi via media whatshap pada 02 Pebruari 2019.

${ }^{9}$ Laporan keuangan ZIS BMT Pahlawan Tulungagung tahun 2017 dan 2017.

${ }^{10}$ Fatkhur Rokhman, Pengelola ZIS BMT Pahlawan Tulungagung, Wawancara pada 19 Juli 2019. 
izin Badan Amil Zakat Nasional Tulungagung. ${ }^{11}$ Jika dilihat dari penyaluran dana zakat, data BMT pengelolaan ZIS pada BMT Pahlawan menunjukkan bahwa alokasi dan penyaluran dana zakat belum sepenuhnya seluruh asnaf terpenuhi. Hal itu terlihat dari alokasi asnaf fakir dan miskin pada Januari 2017 seharusnya Rp. 2.118.805,-, hanya tersalurkan Rp. 1.115.000,-. Begitu juga pada Januari 2018, dari alokasi zakat untuk asnaf fakir miskin Rp. 1.981.821,baru tersalurkan Rp. 360.000,-. Kondisi itu diakui oleh Rokhman, bahwa "dalam penyaluran, belum sepenuhnya memenuhi asnaf yang seharusnya disalurkan. Hal itu pernah dibuat data terpisah, antara infaq dan zakat, dana infaq minus karena sumber terbanyak pengelolaan baitul maal adalah dari zakat BMT. Penyaluran paling banyak adalah untuk beasiswa, masjid dan proposal." 12

Zakat pada BMT Podo Joyo Blitar difahami oleh direktur utama bukan merupakan kewajiban dan tidak ada aturan yang mengharuskan lembaga mengeluarkan zakat. Menurut Suprihno bahwa:

"Lembaga tidak mengeluarkan zakat, karena lembaga tidak menjadi Unit Pengelola Zakat (UPZ) dan tidak mengajukan sebagai pengelola zakat, jadi tidak mengelola zakat. Selain itu zakat merupakan kewajiban perseorangan, oleh karenanya lembaga juga tidak mengeluarkan zakat."13

\section{Infaq}

Infaq pada BMT Pahlawan merupakan bagian dari upaya gotong royong untuk membantu sesama. Pengelolaan infaq pada BMT Pahlawan tahun 2017 mencapai Rp.45.019.206,- (Empat puluh lima juta sembilan belas ribu dua ratus enam rupiah), dan tahun 2018 mencapai Rp. 47.951.850,- (Empat puluh tujuh juta sembilan ratus lima puluh ssatu ribu delapan ratus lima puluh rupiah) artinya secara umum infaq yang diterima BMT mengalami peningkatan sebesar 6,51 persen. Pertumbuhan infaq bulanan, menunjukkan bahwa pertumbuhan terbesar dari penerimaan infaq terjadi pada bulan Mei 2018 yaitu tumbuh sebesar 18,39 persen. Sedangkan pertumbuhan terendah, atau menurun sebesar 1,78 persen pada bulan Juni 2018. Ketentuan infaq menurut Rokhman, adalah

"tidak ada ketentuan dari BMT terkait besaran infaq yang ditawarkan kepada anggota. Anggota yang infaq diantaranya adalah anggota pembiayaan, dan juga ada infaq lainnya yang dimaksud adalah infaq dari anggota simpanan dan juga infaq dari anggota pembiayaan qardh al-Hasan. Namun untuk infaq anggota simpanan dan infaq dari pembiayaan qard al hasan jarang sekali." 14

Penyaluran dana infaq sebagaimana data BMT adalah untuk pembiayaan qardhul hasan, bantuan masjid/mushola, pendidikan, santunan, PHBI, dhuafa. Penyaluran dana infaq dilakukan tiap bulan. Hal itu ditegaskan oleh Rokhman bahwa penyaluran paling banyak adalah untuk beasiswa, masjid dan proposal." 15

Pengelolaan infaq pada BMT Podojoyo Blitar menurut Suprihno, "pengelolaan dalam menerima dana infaq terjadi pada nasabah funding dan juga nasabah financing. Pada nasabah funding, BMT memiliki kebijakan infaq yaitu pada simpanan deposito karena memiliki bagi hasil. Besarnya infaq bagi hasil deposito sebesar 2,5\% dari bagi hasil deposito yang menjadi

${ }^{11}$ Nyadin, Direktur Utama BMT Pahlawan Tulungagung, Konfirmasi via media whatshap pada 02 Pebruari 2019.

${ }^{12}$ Fatkhur Rokhman, Pengelola ZIS BMT Pahlawan Tulungagung, Wawancara pada 19 Juli 2019.

${ }^{13}$ Suprihno, Direktur Utama BMT Podo Joyo Blitar, Wawancara pada 20 Juli 2019.

14 Ibid.

15 Ibid.

20 
hak nya anggota funding deposito. Bagi hasil yang diterima anggota simpanan deposito kurang lebih 1\% / bulan atau kurang lebih 10\% per tahun."16. Konsep ini mengajarkan kepada anggota untuk menjadi muzakky karena bagi hasil dari simpanan mud\}arabah relatif tinggi.

Kebijakan fundraising infaq pada pembiayaan dikelola oleh BMT, merupakan bagian tanggung jawab BMT terhadap anggota karena BMT semata-mata agar bisa berbuat secara sosial kepada masyarakat dan anggota. Sikap lembaga ini akan memiliki citra baik. Menurut Suprihno,

"fundraising infaq ditawarkan oleh BMT kepada anggota berkisar Rp 2.000,- (dua ribu rupiah) sampai dengan Rp. 10.000,- (sepuluh ribu rupiah). Pembiayaan Rp.1.000.000,(satu juta rupiah) sampai dengan Rp.10.000.000,- (sepuluh juta rupiah) ditawarkan infaq sekitar infaq Rp 2.000,- (dua ribu rupiah), di atas Rp.10.000.000,- (sepuluh juta rupiah) kita tawari infaq Rp. 3.000,- (tiga ribu rupiah) sampai Rp. 5.000,- (lima ribu rupiah). dan pembiayaan di atas Rp. 50.000.000,- (lima puluh juta rupiah)., kita tawari infaq 10 Rp. 10.000,- (sepuluh ribu rupiah) atas keikhlasan nasabah. Setiap angsuran langsung ada infaqnya..." 17

Infaq ini mengajarkan kepada anggota untuk bersyukur dan berbagi kepada sesama, bahwa kemudahan-kemudahan yang diterima dari pembiayaan mampu membantu melancarkan kebutuhan hidupnya baik untuk konsumtif maupun untuk usaha. Selain itu infaq juga diterima dari keuntungan simpanan deposito dari anggota. Hal ini mengajarkan kepada anggota untuk berbagi kepada sesama atas rizqi berupa keuntungan yang berhasil di dapat dari penyimpanan dana deposito di BMT Podo Joyo Blitar.

Pengelolaan infaq pada BMT Podo Joyo Blitar tahun 2017 mencapai Rp. 6.530.736,(Enam juta lima ratus tiga puluh ribu tujuh ratus tiga puluh enam rupiah), dan pada tahun 2018 sebesar Rp. 5.017.740,- (Lima juta tujuh belas ribu tujuh ratus empat puluh rupiah). Pengelolaan infaq tersebut tahun 2018 mengalami penurunan sebesar Rp. 1.512.996,- (satu juta lima ratus dua belas ribu sembilan ratus sembilan puluh enam rupiah) atau turun sebesar 23,17 persen. Penurunan terbesar terjadi pada bulan Januari 2018 yakni turun sebesar Rp. 575.907,- (Lima ratus tujuh puluh lima ribu sembilan ratus tujuh rupiah).

Dana infaq yang dikelola BMT disalurkan kepada masyarakat yang membutuhkan. Menurut Suprihno, "dana infaq disalurkan kepada fakir miskin, anak yatim dan janda. Biasanya datang ke RT dan meminta data nama warganya yang masuk kategori fakir miskin, yatim dan janda. Jadi kategori fakir miskin ditentukan oleh RT dari wilayah yang dipilih."18 Masyarakat RT setempat lebih mengetahui kebutuhan warga yang membutuhkan. Penyaluran dana infaq tidak hanya kepada anggota pada BMT, sehingga lebih bersifat terbuka, dan sesuai tujuan sosial lembaga. Potret tersebut menunjukkan kepedulian BMT Podo Joyo Blitar terhadap warga masyarakat yang kurang mampu. Penyaluran dana infaq merupakan gabungan dengan dana sosial yang di keluarkan oleh BMT.

Penyaluran dana infaq menurut Laili, dilakukan tidak setiap bulan, melainkan pada setiap bulan tertentu pada tiap tahunnya. ${ }^{19}$ Bulan tertentu tersebut diantaranya adalah bulan puasa pada tiap tahunnya.

\footnotetext{
16 Ibid.

17 Ibid.

$18 \mathrm{Ibid}$

${ }^{19}$ Anis Nikmatul Laili, Karyawan BMT Podo Joyo Blitar, Wawancara pada 27 Juli 2019. Iqtishadia: Jurnal Ekonomi dan Perbankan Syariah
} 


\section{Dana Sosial Lainnya}

BMT Pahlawan Tulungagung tidak memiliki sumber dana sosial lain selain dana zakat dan infaq. Sebagaimana perusahaan yang berada di bawah perseroan, yang mengharuskan lembaga mengalokasikan dana corporate social responsibility, menurut Rokhman, BMT tidak mengalokasikan dana $\mathrm{CSR}^{20}$ untuk dikelola dalam baitul maal BMT.

BMT Podo Joyo sebagai institusi yang bergerak di bidang keuangan mikro, tak menafikan peranan sosial lainnya. Peran sosial yang dilakukan oleh BMT antara lain mengalokasikan dana sosial sebesar $10 \%$ dari pendapatan pertahun. ${ }^{21}$ Alokasi dana sosial BMT Podojoyo Blitar tahun 2017 sebesar Rp. 2.468.000 (Dua juta empat ratus enam puluh delapan ribu rupiah) dan tahun 2018 sebesar Rp. 4.353.000,- (Empat juta tiga ratus lima puluh tiga ribu rupiah). Pertumbuhan alokasi dana sosial yang tertinggi terjadi pada bulan Juni 2018 yaitu dari Rp. 129.000,- menjadi Rp. 546.000,- atau sebesar 323,26 persen.22 Alokasi dana sosial yang kelola BMT Podo Joyo di alokasikan tiap bulan, sesuai dengan pendapatan yang diperoleh. Dana tersebut sebagai bentuk tanggung jawab sosial lembaga kepada masyarakat di sekitar BMT.

Penyaluran dana sosial bersamaan dengan pengelolaan dana infaq yaitu disalurkan pada fakir miskin, yatim dan janda. ${ }^{23}$ Diharapkan dari masyarakat yang mendapatkan dana tersebut mampu mengurangi beban dalam pemenuhan hidupnya. Dana sosial dan dana infaq yang disalurkan oleh BMT Podo Joyo Blitar secara rutin adalah tahun 2017 sebesar Rp. 1.059.000,- (Satu juta lima puluh sembilan ribu rupiah) yang terinci berupa bantuan sosial sebesar Rp. 550.000,- (lima ratus lima puluh ribu rupiah) dan lain-lain sebesar Rp. 509.000,(Lima ratus sembilan ribu rupiah). Dana sosial 10 persen dari pendapatan didistribusikan secara bulanan mulai bulan Januari hingga Desember. Potret tersebut terjadi pada tahun 2018. Penyaluran dana sosial dalam bentuk lain-lain itu menurut Laili disalurkan kepada masyarakat di lingkungan desa sekitar lokasi koperasi syariah Podojoyo Blitar. ${ }^{24}$

\section{Dana Pembiayaan Qardhal-Hasan}

Pembiayaan Qardhal-hasan di BMT Pahlawan dilakukan setiap bulan. Penyaluran dana qardh tahun 2017 mencapai Rp. 193.121.000,- (Seratus sembilan puluh tiga juta seratus dua puluh satu ribu rupiah) dan tahun 2018 sebesar Rp. 69.829.000,- (Enam puluh sembilan juta delapan ratus dua puluh sembilan ribu rupiah). Kondisi ini dapat dipersentasekan tahun 2018 mengalami penurunan sebesar 63,84 persen. Pertumbuhan tertinggi secara bulanan terjadi pada bulan Januari 2018, yaitu meningkat sebesar 532,5 persen. Dan pertumbuhan menurun tertinggi pada bulan September 2018, menurun sebesar 100 persen. Karena pada bulan tersebut tidak ada penyaluran dana qardh al-hasan. Sumber dana yang digunakan untuk penyaluran dana qardh al-hasan menurut Rokhman di peroleh dari infaq yang berhasil dikelola oleh BMT dan zakat perusahaan (BMT) yang keluar pada setiap bulannya. ${ }^{25}$ Dalam hal ini penyaluran dana qardh al hasan tidak menggunakan dana simpanan mudharabah yang dikelola oleh BMT. Besaran penyaluran dana qardh al-hasan tidak mengikuti persentase dari jumlah asset BMT, ${ }^{26}$ melainkan sesuai dengan pengajuan dan potensi lembaga. Tentu

\footnotetext{
20 Ibid.

${ }^{21}$ Suprihno, Direktur Utama BMT Podo Joyo Blitar, Wawancara pada 20 Juli 2019.

${ }^{22}$ Laporan keuangan ZIS BMT Podo Joyo Blitar tahun 2017 dan 2018.

${ }^{23}$ Suprihno, Direktur Utama BMT Podo Joyo Blitar, Wawancara pada 20 Juli 2019.

${ }^{24}$ Anis Nikmatul Laili, Karyawan BMT Podojoyo Srengat Blitar, Wawancara pada 27 Juli 2019.

25 Ibid.

${ }^{26} \mathrm{Ibid}$

22
} 
dalam penyaluran dana qardh al-hasan tidak semua pengusul dicairkan melainkan sesuai ketentuan yaitu: "dhuafa, fakir/miskin, memiliki usaha, tidak ada jaminan hanya menjaminkan KTP."27

Dana Qardh pada BMT Podojoyo Blitar merupakan kebijakan yang diambil oleh lembaga,28 sebagai bentuk kepedulian terhadap kebutuhan masyarakat yang tidak terhindarkan, namun demikian jika dipandang dari segi profitabilitas, tidak tepat untuk dibebankan. Oleh karenanya sarana untuk sekadar membantu menjadi pertimbangan lembaga.

BMT Podojoyo Blitar memiliki produk pembiayaan Qardh al-hasan. Produk ini bagian dari tanggung jawab sosial lembaga kepada para anggota. Penyaluran pembiayaan Qardh alhasan di BMT Podo Joyo diberikan dalam upaya pemenuhan "membayar kebutuhan orang sakit, melahirkan dan ditegaskan bahwa pembiayaan ini tidak untuk karyawan. Pembiayaan diberikan murni kepada anggota." 29 Pembiayaan ini dijalankan dengan niat membantu kebutuhan anggota yang betul-betul mendesak.

Sumber dana pembiayaan Qardh al-hasan berasal dari infaq yang dikumpulkan oleh BMT dan belum disalurkan pada waktu puasa ataupun Rapat RAT. Hal itu mengingat, simpanan pada BMT adalah simpanan mudharabah. Dampak dari hal ini maka ketersediaan dana Qardh al-hasan terbatas. Sehingga kebijakan lembaga untuk pembiayaan Qardh al-hasan berkisar antara 1 juta rupiah sampai dengan 5 juta rupiah, dengan jangka waktu pembiayaan maksimal 3 bulan. Pembiayaan ini disertai dengan jaminan, dengan harapan anggota tidak lupa terhadap kewajiban mengembalikan pembiayaan. Pembiayaan ini tidak dipungut tambahan keuntungan, melainkan menawarkan seikhlasnya anggota untuk memberikan infaq. ${ }^{30}$ Hal ini mengingat sumber dana Qardh al-hasan berasal dari infaq yang terkumpul.

Penyaluran dana pembiayaan Qardh al-hasan selama tiga tahun terakhir, yaitu pada bulan Pebruari 2018. Jumlah pembiayaan yang disalurkan sebesar Rp. 5.000.000,- rupiah. ${ }^{31}$ Pada bulan-bulan berikutnya belum dilakukan lagi.

\section{Peran Social Finance dalam Menumbuhkan Keuangan Inklusif pada BMT Pahlawan Tulungagung}

Penyaluran dana zakat pada dasarnya berharap agar masyarakat yang disalurkan untuk menjadi muzakky, sehingga pada akhirnya menjadi anggota pada BMT. Namun belum ada upaya untuk menindaklajuti dengan merawat, baik dalam bentuk pendampingan atau sekadar silaturahmi. Namun demikian menurut Rokhman, penyaluran dana zakat, infaq dan qardh al-hasan diharapkan memberikan efek manfaat untuk BMT. ${ }^{32}$ Upaya menumbuhkan semangat berhubungan dan mengakses BMT muncul dalam pembiayaan qardh al-hasan. Mengingat dalam pembiayaan ini, anggota dipastikan agar datang kembali ke BMT untuk membayar hutangnya ke BMT.

Jumlah pemanfaat pembiayaan qardh pada BMT Pahlawan tahun 2017 sebanyak 37 anggota, dan tahun 2018 sebanyak 32 anggota artinya tahun 2018 menurun sebesar 13,51

\footnotetext{
27 Ibid.

28 Suprihno, Direktur Utama BMT Podo Joyo Blitar, Wawancara pada 20 Juli 2019.

29 Suprihno, Direktur Utama BMT Podo Joyo Blitar, Wawancara pada 3 Agustus 2019.

30 Ibid.

31 Collection Data Penelitian dari BMT Podo Joyo Blitar.

32 Fatkhur Rokhman, Pengelola ZIS BMT Pahlawan Tulungagung, Wawancara pada 19 Juli 2019.
} Iqtishadia: Jurnal Ekonomi dan Perbankan Syariah 
persen. ${ }^{33}$ Penggunaan pembiayaan dana Qardh al-hasan yang diperoleh dari BMT Pahlawan menurut penuturan Rezian (27 tahun), ${ }^{34}$ dimanfaatkan untuk menambah modal usaha. Usaha yang dimiliki adalah usaha pisang. Usaha pisang berlokasi di barat SMP 1 Kauman Tulungagung dan setiap hari Minggu jualan di pasar. Keuntungan yang diperoleh menurutnya tidak menentu. Jika kondisi stok pisang banyak, maka bisa jualan pisang dengan jumlah yang banyak, dan jika harga pisang lumayan, maka keuntungan yang diperolehnya juga banyak. Sebaliknya jika harga pisang mahal, dan stok pisang sedikit maka lebih memilih untuk tidak berdagang. Kondisi ini yang menyebabkan Rezian belum bisa menabung, karena kebutuhan sehari-hari banyak dan uang diputar untuk usaha.

Jumlah sasaran anggota yang didanai sehingga termasuk dalam inklusif finance pada tahun 2018 menurun dari 37 anggota (2017) menjadi 32 anggota (2018). Inklusif finance ini menurun sebesar 13, 5 persen. Pada tahun 2018 yang mengalokasikan anggota paling banyak adalah pada bulan April 2018 yaitu sebanyak 10 anggota pembiayaan. Nominal yang disalurkan sebesar Rp. 1.500.000,- (satu juta lima ratus ribu rupiah) masing-masing sama untuk 9 anggota, dan Rp. 2.500.000,- (dua juta lima ratus ribu rupiah) untuk satu anggota. ${ }^{35}$ Pembiayaan ini benar-benar memberikan akses kepada anggota dan memudahkan anggota memenuhi kebutuhan. Hal yang dilakukan oleh BMT Pahlawan terhadap pembiayaan qardh al-hasan adalah sebatas monitoring pembiayaan, belum mengarah kepada potensi bagi anggota untuk menabung di BMT. 36

Inklusif finance pada BMT Pahlawan selain pembiayaan qardh al-hasan, dalam penerapannya berupa layanan kepada masyarakat yang tidak memiliki akses ke BMT, karena usaha belum marketable, belum memberi keuntungan bagi BMT, menjadi konsen BMT untuk dilayani. Layanan ini diantaranya diperuntukkan kepada masyarakat fakir, miskin, dan yatim. Penerimaan dana infaq dan zakat pada BMT Pahlawan dari unsur fakir dan miskin sebagaimana penuturan Mujianto (45 tahun), ${ }^{37}$ digunakan untuk membeli pupuk dan benih guna menggarap lahan sawah. Kesempatan menabung belum bisa dilakukan karena kebutuhan banyak, dan uang yang dimiliki digunakan untuk modal pertanian.

Penggunaan dana bantuan dana zakat, infaq dari BMT Pahlawan untuk unsur penerima yatim sebagaimana penuturan Ardianto (23 tahun),38 digunakan untuk membayar SPP sekolah dan belum dimanfaatkan untuk menabung di BMT.

\section{Peran Social Finance dalam Menumbuhkan Keuangan Inklusif pada BMT Podojoyo Blitar}

Penyaluran dana sosial diharapkan mampu mengurangi beban kehidupan para penerima dana sosial. Penerima dana sosial pada BMT Podo Joyo Blitar adalah fakir miskin, yatim dan janda. Niat utama BMT Podo Joyo adalah murni membantu, sehingga dampak yang ditimbulkan tidak ditindaklanjuti. Namun demikian lembaga memiliki strategi penyaluran untuk yatim, yaitu dilakukan membuka tabungan bagi anak yatim penerima dana infaq dan sosial. Menurut Suprihno:

\footnotetext{
33 Laporan keuangan ZIS BMT Pahlawan tahun 2017 dan 2018.

34 Rizki Rezian, Warga Sukowidodo Barat, Sukowidodo, Karangrejo, Tulungagung, Wawancara pada 26 Juli 2019.

35 Laporan Keuangan ZIS 2018, BMT Pahlawan Tulungagung.

${ }^{36}$ Fatkhur Rokhman, Pengelola ZIS BMT Pahlawan Tulungagung, Wawancara pada 19 Juli 2019.

37 Mujianto, Warga Junjung, Sumbergempol, Tulungagung, Wawancara pada 26 Juli 2019.

38 Titan Wahyu Ardianto, Warga Jepun, Tulungagung, Wawancara pada 26 Juli 2019.

24
} 
"Dana sosial untuk yatim diberikan dalam bentuk uang. Misal dana sosialnya Rp.500.000,- maka Rp.100.000,- diberikan tunai, dan Rp. 400.000,- dalam bentuk tabungan. Karena jika tidak demikian khawatir uang yang diberikan dibuat belanja oleh orang tua. Kita sarankan ambilnya pas masuk sekolah. Ngajari anak menabung..."39

Penyaluran dana infaq dan sosial kepada anak yatim, menurut pengakuan Haikal (10 tahun), ${ }^{40}$ bantuan tersebut diperuntukkan untuk membeli seragam sekolah dan sepatu. Rekening yang dimiliki di BMT belum berlanjut untuk diisi dengan menabung karena belum ada sisa uang untuk ditabungkan. Penuturan yang sama juga disampaikan Dewi (8 tahun), ${ }^{41}$ bahwa bantuan yang diperoleh dari BMT digunakan untuk membeli peralatan sekolah dan membayar iuran sekolah. Menurut Dewi akun tabungan yang dimiliki di BMT digunakan untuk menabung lebih lanjut karena sebagai persiapan kebutuhan akhir sekolah dan lebaran. Penuturan lain disampaikan Dana (11 tahun), ${ }^{42}$ bahwa bantuan dana infaq dan sosial yang diperoleh dari BMT digunakan untuk membeli anak kambing. Upaya menabung Dana dilakukan tidak di BMT melainkan menabung di sekolah.

Kemampuan anak yatim untuk memiliki akun tabungan merupakan upaya bagi BMT untuk mengenalkan dan membiasakan anak untuk menabung. Jika kelak dewasa, dan memiliki penghasilan, tentu peluang ditindaklanjuti oleh anak dan menabungnya diteruskan, maka akan menjadi memberikan kesempatan bagi anak untuk mendapatkan manfaat. Hal ini memberikan dampak bagi bertambahnya anggota funding. Jika yang demikian terawat, maka tidak menutup kemungkinan setelah kelak anak dewasa, memiliki usaha dan dapat bermitra dalam pemenuhan modal dalam bentuk pembiayaan.

Penerima dana sosial lainnya yaitu fakir miskin dan janda, BMT tidak menindaklanjuti terkait pemanfaatan dana sosial yang diberikan. Sehingga BMT tidak mengetahui apakah dengan dana sosial yang disalurkan bermanfaat untuk menjadikan penerima sebagai muzakky baru. Dengan demikian tidak diketahui dampaknya dana sosial terhadap kemampuan penerima dana sosial untuk menabung di BMT dan atau berhubungan dalam pembiayaan. ${ }^{43}$ Peneliti berupaya menggali informasi terkait pemanfaatan dana bantuan dari BMT dan peluang menabung di BMT.

Penerimaan bantuan infaq dan sosial untuk fakir miskin seperti penuturan Alfiah, ${ }^{44}$ (54 tahun), diperuntukkan guna membeli kebutuhan rumah tangga, membeli sembako, termos air panas. Sampai dengan saat wawancara berlangsung, ibu Alfiah belum bisa menabung di BMT karena belum bisa menyisihkan uang untuk menabung. Penerimaan bantuan infaq dan sosial untuk fakir miskin lebih lanjut sebagaimana penuturan Mulyati (54 tahun),45 digunakan untuk berobat atas sakit asam urat dan kolesterol yang dideritanya. Potensi menabung menurutnya belum bisa dilakukan karena kebutuhannya belum tercukupi. Penerimaan bantuan infaq dan sosial untuk fakir miskin juga disampaikan oleh Budiman (53 tahun), ${ }^{46}$ digunakan untuk membeli cangkul dan clurit guna mendukung pekerjaannya

\footnotetext{
${ }^{39}$ Suprihno, Direktur Utama BMT Podo Joyo Blitar, Wawancara pada 20 Juli 2019.

${ }^{40}$ Fikri Haikal, Warga Kolomayan, Wonodadi, Blitar Wawancara pada 27 Juli 2019.

${ }^{41}$ Risma Ayu Dewi, Warga Jatilengger, Wonodadi, Blitar Wawancara pada 27 Juli 2019.

42 Fikri Aula Dana, Warga Srengat, Blitar Wawancara pada 27 Juli 2019.

43 Suprihno, Direktur Utama BMT Podo Joyo Blitar, Wawancara pada 20 Juli 2019.

${ }^{44}$ Alfiah, Warga Togogan, Srengat, Blitar, Wawancara pada 27 Juli 2019.

45 Sri Mulyati, Warga Jatilengger, Srengat, Blitar Wawancara pada 27 Juli 2019.

46 Sri Budiman, Warga Bakung, Udanawu, Blitar Wawancara pada 27 Juli 2019
} 
sebagai buruh tani. Namun demikian hasil dari buruh tani belum bisa digunakan untuk menabung karena belum bisa menyisihkan uang untuk ditabung.

Penerimaan bantuan infaq dan sosial untuk janda sebagaimana penuturan Khoiriyah ${ }^{47}$ (48 tahun), diperuntukkan untuk kebutuhan sekolah anak, dan belum berkesempatan menabung di BMT karena ada sisa uang yang bisa ditabungkan. Penuturan lain dari penerima dana infaq dan sosial dari unsur janda sebagaimana yang disampaikan Rahmah ${ }^{48}$ (46 tahun) bahwa bantuan yang diterima dari BMT digunakan untuk kebutuhan rumah tangga guna membeli sembako. Kesempatan menabung menurutnya belum bisa dilakukan karena belum bisa menyisihkan uang untuk di tabung. Penerimaan dana infaq dan sosial dari unsur janda lainnya sebagaimana disampaikan Winarti (47 tahun),49 digunakan untuk jualan sayur matang. Kesempatan menabung dilakukan Winarti di BMT Podojoyo Blitar karena pelayanannya bagus, karyawannya ramah (kekeluargaan).

Penyaluran dana sosial yang lain berupa Qardh al-hasan diperuntukkan bagi kebutuhan pembayaran orang sakit, melahirkan. ${ }^{50}$ Penyaluran dana Qardh al-hasan baru terjadi sekali, yaitu pada Pebruari 2018. Jumlah pembiayaan yang disalurkan sebesar Rp. 5.000.000,rupiah. ${ }^{51}$. Penerima pembiayaan tersebut adalah Srikah ${ }^{52}$ (60 tahun), pembiayaan dana Qardh al-hasan yang diterimanya digunakan untuk berobat di rumah sakit akibat sakit struk yang dideritanya. Pembiayaan Qardh al-hasan sejatinya dialokasikan terus oleh BMT Podojoyo, namun menurut Laili, dari pengajuan anggota, hanya satu tersebut yang layak untuk didanai. 53

Pembiayaan memang peminatnya banyak, namun mengingat pembiayaan ini bersifat sosial, dan sumber dana yang digunakan adalah dari sumber dana infaq dan dana sosial BMT maka pembiayaan dialokasikan pada anggota yang benar-benar membutuhkan dan sesuai kriteria penerima infaq dan sosial lainnya.

Bantuan dana sosial yang dikeluarkan oleh BMT Podo Joyo Blitar sebagaimana penuturan Mariyati ${ }^{44}$ (47 tahun), dana sosial yang diterimanya digunakan untuk modal usaha membeli ayam kampung yang diambil telurnya. Menurutnya keuntungan tiap hari yang diperoleh kurang lebih Rp. 5.000,- (Lima ribu rupiah). Kesempatan menabung belum bisa dilakukan karena keuntungan yang masih sedikit.

Penerimaan dana sosial lainnya menurut penuturan Robiah ${ }^{55}$ (50 tahun) digunakan untuk jualan jajanan dan minuman anak-anak. Keuntungan yang diperoleh tiap harinya kurang lebih Rp. 15.000,- (Lima belas ribu rupiah). Namun demikian potensi menabung di BMT belum bisa dilakukan karena belum cukup uang untuk menyisihkan untuk menabung. Menurut penuturannya ibu Rahmah tetap akan melakukan pembiayaan ulang untuk menambah modal dan mengembangkan usaha. Pilihan pembiayaan ulang dipilih di BMT Podojoyo, hal ini dikarenakan BMT Podojoyo telah memberikan stimulan (pancingan) modal usaha.

\footnotetext{
${ }^{47}$ Khoiriyah, Warga Togogan, Srengat, Blitar, Wawancara pada 27 Juli 2019

48 Miftakhur Rahmah, Warga Udanawu, Udanawu, Blitar, Wawancara pada 27 Juli 2019

${ }^{49}$ Sri Winarti, Warga Cangkring, Ponggok, Blitar Wawancara pada 27 Juli 2019

50 Suprihno, Direktur Utama BMT Podo Joyo Blitar, Wawancara pada 20 Juli 2019.

51 Collection Data Penelitian dari BMT Podo Joyo Blitar

52 Srikah, Warga Jatilengger, Ponggok, Blitar, Wawancara pada 27 Juli 2019

53 Anis Nikmatul Laili, Karyawan BMT Podo Joyo Blitar, Wawancara pada 27 Juli 2019.

54 Mariyati, Warga Togogan, Srengat, Blitar, Wawancara pada 27 Juli 2019

${ }^{55}$ Robiah, Warga Togogan, Srengat, Blitar, Wawancara pada 27 Juli 2019

26
} 
Penerimaan dana sosial lainnya menurut penuturan Khatidjah ${ }^{56}$ (40 tahun) digunakan untuk tambahan modal jualan sayur keliling (etek). Keuntungan rata-rata tiap hari kurang lebih RP. 35.000,- (Tiga puluh lima ribu rupiah). Peluang menabung belum bisa dilakukan karena keuntungan hanya cukup untuk kebutuhan sehari-hari. Namun demikian ibu Khatidjah tetap melakukan pembiayaan ulang ke BMT untuk memberikan tambahan modal usahanya. Pilihan pembiayaan ulang dilakukan di BMT Podojoyo karena persyaratan mudah, pelayanan baik dan persaudaraan sudah terbangun cukup lama.

Penyaluran dana sosial dalam bentuk lain-lain itu menurut Laili disalurkan kepada masyarakat di lingkungan desa sekitar lokasi koperasi syariah Podojoyo Blitar. ${ }^{57}$ Kepedulian BMT terhadap lingkungan desa menjadi satu upaya mendekatkan BMT sesuai kebutuhan lingkungan setempat, sehingga kehadiran BMT bisa dirasakan masyarakat sekitar.

Kebaikan yang diberikan BMT senantiasa memberikan citra positif bagi lembaga. Sehingga akan memberikan rasa nyaman dan kedekatan dengan anggota. Saat anggota memiliki uang maka akan menyimpannya pada BMT, dan pada saat melakukan usaha maka kerjasama dengan BMT dalam pemenuhan kebutuhan.

\section{Analisis Implementasi Social Finance pada BMT Pahlawan Tulungagung dan BMT Podo Joyo Blitar}

Sumber dana social finance pada BMT di kedua wilayah ini memiliki perbedaan dan persamaan pada pelaksanaanya. Perbedaannya pada zakat lembaga. BMT Pahlawan memiliki rutinitas zakat lembaga yang dikeluarkan pada tiap bulannya, sedangkan pada BMT Podo Joyo berkeyakinan bahwa zakat hanya dikeluarkan karena kewajiban perorangan. Namun sebaliknya BMT Pahlawan tidak mengeluarkan dana sosial (corporate social responsibiity) sedangkan BMT Podojoyo mengeluarkan dana sosial sebesar $10 \%$ dari pendapatan yang dimiliki dalam setahunnya.

Badan Amil Zakat Nasional (Baznas) menganalogkan zakat perusahaan sebagai zakat perdagangan. Nishab yang menjadi standar adalah nishab zakat perdagangan sebesar 85 gram emas. ${ }^{58}$ Zakat perusahaan dihitung dengan rumus:

Zakat Perusahaan $=2,5 \% \mathrm{x}$ (aset lancar - hutang jangka pendek).

Nishab zakat seharga 85 gram emas, jika per gramnya bernilai Rp. 622.000,- (Enam ratus dua puluh dua ribu rupiah) maka batasan nishab adalah sebesar Rp. 52.870.000,- (Lima puluh dua juta delapan ratus tujuh puluh ribu rupiah). Implementasi zakat yang dikeluarkan BMT sebesar 2,5\% dari pendapatan. Hal ini berbeda dengan apa yang menjadi kebijakan pada badan amil zakat nasional. Pemahaman dan keyakinan pengelola menjadi bagian dari penentuan zakat yang dikeluarkan oleh BMT.

Keyakinan terhadap kesadaran zakat bagi lembaga penting untuk ditumbuhkan. Sinergi antara lembaga-lembaga bisnis mampu mendongkrak potensi zakat. Harapannya semakin meningkat alokasi zakat yang dikeluarkan oleh lembaga, perusahaan dan lebih khusus kepada BMT sehingga menurut Ridlo bisa menjadi sumber peningkatan perekonomian umat. ${ }^{59}$ Zakat yang dikelola oleh BMT akan membantu lembaga sebagai sumber dana sosial yang berdampak bagi peningkatan kesejahteraan bagi anggota maupun masyarakat sekitar

${ }^{56}$ Siti Khatidjah, Warga Udanawu, Udanawu, Blitar, Wawancara pada 27 Juli 2019.

${ }^{57}$ Anis Nikmatul Laili, Karyawan BMT Podojoyo Srengat Blitar, Wawancara pada 27 Juli 2019.

${ }^{58}$ Zakat Perusahaan, diakses pada https://baznas.go.id/id/zakat-perusahaan.

${ }^{59}$ Ridlo, "Zakat Dalam Perspektif Ekonomi Islam." 
BMT. Sinergi zakat yang bisa dikelola BMT menjadi penting untuk dibudayakan. Selain itu keyakinan lembaga bahwa laba yang diperoleh akan halal menjadi lebih terang benderang, karena sudah memperhatikan dan ikut bertanggung jawab kepada masyarakat sekitar.

Zakat berbeda dengan infaq. Zakat dalam penyalurannya diperuntukkan kepada 8 asnaf yang berhak menerima zakat. Penyaluran zakat khusus asnaf fakir miskin sebagaimana alokasi 1/8 dari total zakat yang terkumpul, maka pada tahun 2017 dan 2018, penyaluran khusus untuk fakir dan miskin masih tersisa. Peruntukan ini perlu diperhatikan karena dana yang dikelola adalah amanah dari nasabah agar tersampaikan dengan baik. Merujuk pada distribusi zakat BMT Pahlawan Januari 2017, zakat didistribusikan dalam bentuk beasiswa, bantuan yatim, bantuan fakir. Adapun alokasi asnaf yang seharusnya 1/8 dari dana zakat, masih sisa sebesar Rp. 1.003.805,- (Satu juta tiga ribu delapan ratus lima rupiah). Distribusi zakat Januari 2018 diperuntukkan untuk beasiswa dan fakir. Sisa pada tahun 2018 sebesar Rp. 1.621.821,- (Satu juta enam ratus dua puluh satu ribu delapan ratus dua puluh satu rupiah). ${ }^{60}$ Menurut paparan Rakhman, distribusi zakat tidak memakai pedoman alokasi asnaf, tetapi sesuai pengajuan nasabah dan tidak didasarkan penerimaan langsung didistribusikan. Distribusi paling banyak disalurkan pada bulan Ramadlan. Distribusi untuk fakir berupa sembako, miskin dalam bentuk sembako dan beasiswa anak kurang mampu, gharim untuk pelunasan hutang, dan amil adalah untuk pengelola. ${ }^{61}$ Kemanfaatan zakat bisa langsung dirasakan oleh penerima zakat, tidak mengkhususkan asnaf. Kemanfaatan penyaluran zakat seyogyanya bisa dimanfaatkan sesua asnaf sebagaimana dalam al-Qur'an. Oleh karenanya pengelolaan zakat dikelola secara profesional.

Pengelolaan zakat secara profesional dan akuntabel ${ }^{62}$ menjadikan kesadaran ${ }^{63}$ dan kepercayaan para muzakky yaitu para anggota BMT semakin meningkat. Pengelolaan zakat sebagaimana dalam undang-undang antara lain dilakukan dengan "kegiatan perencanaan, pelaksanaan, dan pengkoordinasian dalam pengumpulan, pendistribusian, dan pendayagunaan zakat". ${ }^{64}$ Keyakinan para muzakky bahwa zakat dan infaq dikelola sehingga zakat tersalurkan dengan baik menjadi modal untuk merealisasikan potensi zakat.

Pengelolaan zakat di BMT Pahlawan belum memiliki legalitas Unit Pengelola Zakat, namun secara legal bahwa BMT itu adalah Baitul Maal melekat pada nama yang tertera dalam payung hukum BMT. Operasional pengelolaan zakat masih belum memiliki standar operasional prosedur baik dalam hal funding maupun distribusi zakat. ${ }^{65}$ Kedepan penting kiranya dimaksimalkan bahwa BMT memiliki potensi untuk menjadikan baitul maal yang sesungguhnya, bersanding di bawah pengelolaan baznas, maka akan semakin melengkapi kehadiran zakat yang bisa drasakan oleh masyarakat. Tujuan dari pengelolaan zakat adalah "meningkatkan efektivitas dan efisiensi pelayanan dalam pengelolaan zakat, meningkatkan manfaat zakat untuk mewujudkan kesejahteraan masyarakat dan penanggulangan

\footnotetext{
${ }^{60}$ Laporan ZIS 2017 dan 2018, BMT Pahlawan Tulungagung.

${ }^{61}$ Fatkhur Rakhman, Pengelola ZIS BMT Pahlawan, wawancara pada 2 Agustus 2019.

${ }^{62}$ Siti Nurhasanah, "Akuntabilitas Laporan Keuangan Lembaga Amil Zakat Dalam Memaksimalkan Potensi Zakat," Jurnal Ilmu Akuntansi 11, no. 2 (2018).

${ }^{63}$ Herfita Rizki Hasanah Gurning and Haroni Doli Hamoraon Ritonga, "Analisis Tingkat Kesadaran Masyarakat Kecamatan Medan Baru Dalam Membayar Zakat," Jurnal Ekonomi da Keuangan 3, no. 7 (n.d.).

64 Pasal 1, Undang-Undang Nomor 23 Tahun 2011 Tentang Pengelolaan Zakat.

${ }^{65}$ Fatkhur Rakhman, Pengelola ZIS BMT Pahlawan, wawancara pada 2 Agustus 2019.

28
} 
kemiskinan".66 Tujuan mulia zakat inilah yang menjadikan sinergi antara BMT dan badan amil zakat.

Zakat sebagai nilai bagi lembaga keuangan syariah (BMT) menurut Meutia67 mencerminkan tanggungjawab bank syariah dalam mewujudkan kesejahteraan bagi seluruh masyarakat, yang di dalamnya terdapat masyarakat yang masuk kategori ekonomi menengah ke bawah. Zakat mempunyai definisi etimologi dan terminologi. Secara etimologi zakat dimaknai sebagai yang "berkah, bersih, tumbuh dan berkah. Sedangkan secara terminologi, zakat dimaknai sebagai kadar harta tertentu yang diberikan kepada yang berhak menerimanya dengan beberapa syarat".68 Zakat yang diberikan kepada penerima zakat diharapkan memberikan keberkahan bagi harta yang pemilik dan juga penerima. Bagi pemilik harta, maka rasa syukur dengan mengeluarkan zakat akan dilimpahkan nikmatnya oleh Allah SWT. Sedangkan bagi penerima zakat, zakat ini akan memberikan dampak kesejahteraan karena dengan zakat akan membantu terpenuhi kebutuhan mustahiq. Dengan demikian akan menciptakan kebahagian bagi mustahiq. Dan jika dengan uang zakat ini mampu diberdayakan untuk usaha mustahiq, maka tidak mustahil akan meningkatkan pendapatan bagi mustahiq dan meningkatkan status mustahiq menjadi muzakky.

Zakat merupakan upaya pemenuhan rukum islam yang kedua. Pengelolaan zakat selain diatur dalam dalil, juga diatur oleh hukum positif dalam Undang-Undang Nomor 23 tahun 2011 tentang pengelolaan zakat dalam kerangka meningkatkan daya guna, hasil guna zakat bagi masyarakat. Zakat memiliki manfaat bagi penerima dan masyarakat pada umumnya. Menurut Aziz bin Bas, "zakat meningkatkan kasih sayang antara si kaya dan si miskin, membersihkan diri dari sifat rakus dan tamak, membiasakan keramahan dan empati, membawa keberkahan terhadap harta" ${ }^{6}$. Zakat yang sudah disalurkan memberikan dampak sosial bagi pemenuhan kebutuhan dan munculnya rasa kasih sayang terhadap sesama. Jika hal demikian disalurkan oleh lembaga keuangan syariah, maka akan meningkatkan citra baik lembaga di masyarakat. Perhatian lembaga keuangan syariah kepada masyarakat semakin dirasakan tidak hanya yang berkaitan dengan anggota yang memiliki kemampuan bisnis melainkan kepada yang tidak memiliki juga.

Potensi zakat yang diprediksi oleh Baznas antara lain terdiri dari zakat rumah tangga, zakat industri swasta, zakat BUMN, dan potensi zakat tabungan.70 $\mathrm{Hal}$ itu sebagaimana definisi zakat dalam undang-undang, bahwa zakat adalah "harta yang wajib dikeluarkan oleh seorang muslim, atau badan usaha, untuk diberikan kepada yang berhak menerimanya sesuai dengan syariah Islam"71 Zakat rumah tangga yang dimaksud adalah zakat penghasilan di atas batas nishab zakat pertanian 524 kg beras, dengan zakat 2,5\% yang dianalogkan dengan zakat emas dan perak. Zakat industri swasta, BUMN sebesar 2,5\% dari laba yang berhasil di

\footnotetext{
66 Pasal 3, Undang-Undang Nomor 23 Tahun 2011 Tentang Pengelolaan Zakat.

${ }^{67}$ I. Meutia, Shari"ah Enterprise Theory Sebagai Dasar Pengungkapan Tanggungjawab Sosial Bank Syariah (Universitas Brawijaya Malang, 2009).

${ }^{68}$ Ali Ridlo, “Zakat Dalam Perspektif Ekonomi Islam," Jurnal Al - 'Adl 7, no. 1 (2014): 19.

69 Syaikh Abdul Aziz bin Baz, Zakat, trans. Ummu Abdillah al-Buthoniyah, 2009, 1-3, http://www.raudhatulmuhibbin.org.

70 Tim Penyusun Direktorat Pemberdayaan Zakat, Zakat Community Development; Model Pengembangan Zakat (Direktorat Jenderal Bimbingan Masyarakat Islam, Direktorat Pemberdayaan Zakat, 2013), 3.

71 Undang-Undang Nomor 23 Tahun 2011, Tentang Pengelolaan Zakat, Pasal 1
} 
dapat oleh perusahaan. Hal inilah yang dianalogkan sehingga lembaga keuangan syariah seperti BMT merupakan bagian yang berhak mengeluarkan zakat.

Diantaranya Zakat yang dikeluarkan oleh lembaga keuangan Syariah harus mencapai haul dan nisab. Zakat bagi lembaga keuangan syariah seperti halnya zakat perniagaan dalam bisnis. Menurut Aziz bin Baz, tabungan dan pinjaman memiliki kewajiban untuk dikeluarkan zakatnya. Pada pinjaman yang wajib dizakati adalah pinjaman (baik untuk konsumtif maupun untuk usaha) yang berpotensi untuk dikembalikan, sedangkan yang tidak dikembalikan maka tidak wajib dikeluarkan zakatnya. ${ }^{72}$ Hal inilah yang memberikan keharusan lembaga keuangan syariah mengeluarkan zakat, karena dalam lembaga keuangan syariah berurusan dengan pengelolaan tabungan dan pinjaman serta pembiayaan.

Zakat lembaga keuangan syariah disalurkan kepada amil zakat untuk dapat disalurkan ke delapan asnaf penerima. Sebagaimana dalam firman Allah dalam surat at-Taubah ayat 60, "Sesungguhnya zakat-zakat itu, hanyalah untuk orang-orang fakir, orang-orang miskin, pengurus-pengurus zakat, Para mu'allaf yang dibujuk hatinya, untuk (memerdekakan) budak, orang-orang yang berhutang, untuk jalan Allah dan untuk mereka yuang sedang dalam perjalanan, sebagai suatu ketetapan yang diwajibkan Allah, dan Allah Maha mengetahui lagi Maha Bijaksana."73 Ayat di atas menjelaskan kepada pengelola zakat, infaq maupun shadaqah, bahwa pemanfaatan atas dana zakat infaq dan shadaqah ada kekhususan tersendiri, dan tidak sembarang orang bisa diberi. Kemiskinan sebagaimana ayat tersebut diungkap oleh dkementerian agama adalah terkait ketidakmemadaian kondisi perumahan dan ekonomi keluarga (rumah reot, minimnya perlengkapan, MCK tidak dimiliki), fisik yang lemah, keterasingan (isolation), kerentanan (vulnerability) seperti musim paceklik. ${ }^{74}$

Baitul Maal wat Tamwil memiliki institusi Baitul maal maka BMT dapat menyalurkan zakat dan infaq langsung kepada anggotanya. Pengelolaan dana yang berhasil dikumpulkan oleh Badan Amil Zakat Nasional (Baznas) yang tertinggi adalah dari zakat yaitu sebesar 63,29 persen pada tahun 2015.750utlook pengelolaan zakat 2018 menunjukkan adanya peningkatan pengumpulan zakat pada tahun 2016. Sedangkan infaq mengalami penurunan di tahun yang sama. Zakat tersebut diakui oleh Baznas merupakan pengumpulan zakat fitrah dan zakat profesi. Sementara potensi zakat lainnya perlu direncanakan dan dikelola dengan baik. Jika potensi zakat tersebut mampu dikelola dengan baik, akan memberi dampak bagi pengembangan ekonomi di masyarakat. Zakat mampu menumbuhkan kemampuan masyarakat memenuhi kebutuhannya. Selain itu dengan zakat berpotensi membantu membuka usaha baru bagi masyarakat.

Menurut Bank Indonesia, zakat akan memberikan perubahan perilaku konsumsi baik secara makro atupun mikro. Secara mikro zakat akan memberikan dampak pada peningkatan tingkat konsumsi mustahik. ${ }^{76}$ Dalam konteks demikian zakat memberikan dampak perubahan pada gaya hidup seseorang, tentu bagi muzakki yang benar-benar mendapatkan kesadaran, hidayah dalam menunaikan kewajiban sosialnya kepada sesama, tanpa pamrih namun membawa keberkahan yang tidak disangka-sangka. Zakat menurut Bank Indonesia memberikan pengaruh dalam hal investasi antara lain pertama, zakat dipungut atas harta

\footnotetext{
72 Aziz bin Baz, Zakat, 22-24.

73 QS. At-Taubah [9] ayat 60, Alqur'an dan Terjemahan.

74 Tim Penyusun Direktorat Pemberdayaan Zakat, Zakat Community Development; Model Pengembangan Zakat, 18.

75 Outlook Pengelolaan Zakat tahun 2018.

76 Bank Indonesia, Pengelolaan Zakat Yang Efektif: Konsep Dan Praktik Di Berbagai Negara (Jakarta: Bank Indonesia dan UII, 2016), 37.
}

30 
yang menganggur, misalnya adanya haul dan nishab. Dengan zakat ini maka mendorong seseorang yang menerima dana zakat untuk produktif,77 misalnya pertama, membuat usaha peyek dengan modal lima ratus ribu rupiah, akhirnya barangnya laku dan mendapat keuntungan. Usaha gorengan ini memberi dampak kesejahteraan karena pendapatannya meningkat. Zakat yang mendorong investasi meningkat, maka dalam proses investasi berdampak pada permintaan tenaga kerja. Aset yang meningkat maka akan meningkatkan kebutuhan tenaga kerja, karena diharapkan output akan meningkat seiring modal dan output yang diharapkan meningkat. Kemampuan daya beli muzaki yang meningkat membuat permintaan barang akan meningkat, sehingga produsen semakin giat memenuhi permintaan konsumen. Secara umum zakat memberi manfaat untuk "memberdayakan ekonomi umat, mengentaskan kemiskinan, membuka lapangan pekerjaan, meningkatkan kesehatan, meningkatkan kualitas pendidikan mustahik dan meningkatkan kesejahteraan taraf hidup bagi mustahik."78

Zakat dalam pengelolaannya dapat didayagunakan untuk usaha produktif bagi kepentingan fakir dan miskin serta peningkatan kualita umat. Namun demikian hal ini dapat dilakukan apabila kebutuhan dasar bagi mustahik sudah terpenuhi. ${ }^{79}$

Selain zakat, infaq merupakan instrumen dana sosial yang sama-sama dikelola oleh kedua BMT. Kedua BMT baik BMT Pahlawan Tulungagung, maupun BMT Podo Joyo Blitar mengelola infaq tiap bulannya. Infaq yang berhasil dikelola oleh BMT Pahlawan rata-rata tiap bulan pada tahun 2018 mencapai Rp. 3.955.988,- (Tiga juta sembilan ratus lima puluh lima ribu sembilan ratus delapan puluh delapan rupiah) sedang di BMT Podo Joyo RP. 418.145,(Empat ratus delapan belas ribu seratus empat puluh lima rupiah). Jumlah ini merupakan capaian signifikan, apalagi jika dimaksimalkan dengan pengelolaan secara maksimal, maka akan terus bertambah dan memberi manfaat bagi anggota maupun masyarakat pada umumnya.

Pendistribusian dana infaq lebih fleksibel dibandingkan dengan pengelolaan dana zakat. Zakat secara filosofi harus disegerakan karena harta itu milik fakir dan miskin serta asnaf lainnya yang betul-betul membutuhkan. Sementara infaq, pendistribusian bisa bertahan hingga uang tersebut bisa disalurkan sesuai kebutuhan, di kelola secara produktif sehingga memberikan nilai secara kuantitas dan bisa dibagi kepada lebih banyak orang.

Infaq memiliki makna yang berbeda jika dibandingkan dengan zakat. Infaq adalah "pengeluaran dari harta seseorang setiap kali ia mendapatkan rizqi sesuai yang dia kehendakinya." 80 Infaq dikeluarkan pada pada harta tanpa mempersyaratkan haul dan nishab. Harta yang dikeluarkan merupakan bukti kasih sayang pemilik harta kepada sesamanya dalam bentuk pemberian yang ikhlas. Dalil tentang infaq adalah "mereka yang beriman kepada yang ghaib, yang mendirikan shalat, dan menafkahkan sebahagian rizqi yang Kami anugerahkan kepada mereka."81 Rizqi merupakan segala yang dapat diambil manfaatnya. Sedangkan menafkahkan sebagian rizqi adalah memberikan sebagian dari harta

77 Bank Indonesia, Pengelolaan Zakat Yang Efektif: Konsep Dan Praktik Di Berbagai Negara (Jakarta: Bank Indonesia dan UII, 2016), 41.

78 Tim Penyusun Direktorat Pemberdayaan Zakat, Zakat Community Development; Model Pengembangan Zakat, 32.

79 Undang-Undang Nomor 23 Tahun 2011, Tentang Pengelolaan Zakat, Pasal 27.

80 Bank Indonesia, Wakaf: Pengaturan Dan Tata Kelola Yang Efektif (Jakarta: Bank Indonesia dan Universitas Airlanggga, 2016), 39-40.

${ }^{81}$ Al-Qur'an dan Tarjamah, Surat al-Baqarah [2] ayat 3.

Iqtishadia: Jurnal Ekonomi dan Perbankan Syariah 
yang telah direzkikan oleh Tuhan kepada orang-orang yang disyari'atkan oleh agama memberinya, seperti orang-orang fakir, orang-orang miskin, kaum kerabat, anak-anak yatim dan lain-lain. Infaq dapat diberikan sewaktu-waktu. Infaq sebagaimana dalam definisi pada Undang-Undang pengelolaan zakat adalah "harta yang dikeluarkan oleh seseorang atau badan usaha di luar zakat untuk kemaslahatan umum." 82

Wakaf memiliki makna antara lain "pemberian seseorang secara ikhlas berupa benda bergerak atau tidak bergerak bagi kepentingan umum yang dibentuk yang berkaitan dengan dengan agama Islam. Dengan kata lain wakaf adalah bentuk donasi yang diberikan seseorang yang bersifat sukarela dengan dana atau pokok wakafnya tetap terjaga atau terpelihara."83 Wakaf memiliki ketentuan antara lain; pertama; harta wakaf lepas/putus dari hak milik wakif, kecuali pendapat Hanafiyah, Malikiyah dan hukum positif. Kedua, harta wakaf harus kekal, kecuali pendapat Malikiyah yang mengatakan bahwa boleh mewakafkan sesuatu walaupun akan habis dengan sekali pakai, seperti makanan asalkan manfaatnya berlanjut. Ketiga, Yang disedekahkan hanyalah manfaatnya saja. ${ }^{84}$ Wakaf dalam lembaga seperti BMT yang tepat adalah wakaf uang. Diantara jenis wakaf benda bergerak adalah berupa uang, logam mulia, surat berharga, kendaraan, Hak kekayaan intelektual, hak sewa dan lain-lain yang sesuai dengan syariah. ${ }^{85}$ Jika wakaf bergerak ini dijalankan pada lembaga keuangan, maka sustainability lembaga keuangan, di tengah persaingan bisnis keuangan, maka akan kuat bersaing dan mampu mengejar ketertinggalan.

Implementasi dana sosial pada BMT Podojoyo bisa merupakan tanggungjawab sosial BMT terhadap lingkungan masyarakat dan sebagai upaya mewujudkan aturan undangundang perseroan. ${ }^{86}$ Aturan undang-undang tersebut menjelaskan bahwa "perseroan yang menjalankan kegiatan usahanya di bidang dan atau berkaitan dengan sumber daya alam wajib melaksanakan tanggung jawab sosial dan lingkungannya." 87 Jika merujuk hal tersebut, BMT Podo Joyo Blitar berjalan dalam legalitas koperasi, sehingga bukan termasuk pada perseroan terbatas. Sebagaimana pasal 74 pada undang-undang tersebut, BMT Podo joyo tidak bergerak dalam kegiatan usaha di bidang sumber daya alam, maka akan lebih tepat jika BMT mengeluarkan dana sosial dalam bentuk zakat. Keyakinan bahwa zakat menjadi bagian tanggung jawab sosial dalam islam sudah menjadi kebijakan badan amil zakat nasional selaku ulil amri yang harus dipatuhi.

Zakat menjadikan harta yang dikelola oleh BMT menjadi lebih berkah dan berkembang. Harta yang dikelola sudah memiliki tanggung jawab dalam Islam terhadap anggota maupun masyarakat lain yang memiliki status kurang mampu. Perputaran ekonomi tidak hanya berputar pada orang yang memiliki simpanan maupun akses pembiayaan pada BMT. Masyarakat yang kurang mampu akan memiliki prioritas mendapatkan bantuan guna memenuhi kebutuhan hidupnya. Zakat memiliki citra yang lebih baik dibanding dengan dana sosial, karena memberi keyakinan memenuhi ketentuan rukun Islam. BMT memiliki posisi di hati masyarakat ketika menyalurkan dana zakat, sehingga memberikan peluang bagi

\footnotetext{
82 Undang-Undang Nomor 23 Tahun 2011, Tentang Pengelolaan Zakat, Pasal 1.

83 Bank Indonesia, Wakaf: Pengaturan Dan Tata Kelola Yang Efektif, 40.

84 Ibid., 41.

85 Ibid., 42.

86 Undang-Undang Nomor 40 Tahun 2007 Tentang Perseroan Terbatas. Perseroan Terbatas adalah badan hukum yang merupakan perseteruan modal, didirikan berdasarkan perjanjian, melakukan kegiatan usaha dengan modal dasar yang seluruhnya terbagi dalam saham dan memenuhi persyaratan yang ditetapkan dalam undang-undang ini dan aturan pelaksanaannya.

${ }^{87}$ Bab V, Pasal 74, Ayat 1, Undang-Undang Nomor 40 Tahun 2007 Tentang Perseroan Terbatas. 
masyarakat menjadi anggota dan menitipkan uangnya pada BMT. Selain itu bagi masyarakat yang memiliki usaha akan melibatkan BMT dalam penambahan modal untuk pengembangan bisnisnya dengan menjadi anggota pembiayaan.

Penyaluran dana Qardh al-hasan pada kedua BMT dilaksanakan tiap bulan. Sumber dana yang digunakan adalah sumber dana dari infaq, dan tidak menggunakan sumber dana dari simpanan nasabah funding. Pada BMT Pahlawan alokasi penyaluran dana dengan produk ini menurun pada tahun 2018 dibandingkan tahun 2017, sedangkan pada BMT Podo Joyo, baru teralokasi sekali pada tahun 2018. Hal ini terjadi karena keterbatasan alokasi sumber dana pembiayaan Qardh al-hasan pada kedua BMT ini. Guna meningkatkan alokasi pembiayaan Qardh al-hasan maka bisa digunakan strategi memanfaatkan alokasi sumber dana simpanan nasabah funding untuk skim wadiah. ${ }^{88}$ Skim ini tidak mensyaratkan bagi hasil bagi nasabah, oleh karenanya tidak menjadi beban BMT untuk mencarikan keuntungan. Sumber dana pembiayaan Qardh al-hasan bisa digunakan untuk pembiaan Qardh, yang memastikan pinjaman itu kembali. Simpanan wadiah ini berlangsung di BMT Surya Mandiri Mlarak Ponorogo,89 meski pada umumnya simpanan anggota BMT lain adalah simpanan mudharabah. Namun demikian meski simpanan wadiah, sustainability dapat berjalan baik.

Dana sosial berbeda dengan dana zakat yang jelas keperuntukannya. Dana sosial bersifat umum, diberikan kepada yang membutuhkan. Dana sosial dapat diperuntukan dalam bentuk sarana dan fasilitas umum seperti membangun pos kamling, swadaya masyarakat membangun jalan, pemberian sembako dll. Sebagaimana tabel 1. Baznas juga melakukan pengelolaan dana sosial, namun yang bersifat keagamaan. Nominal pada tahun 2016 mengalami peningkatan dibandingkan tahun 2015.90 Peran dana sosial keagamaan tersebut fokus untuk layanan dan peningkatan sarana ibadah. Jika ini terus berjalan, maka ibadah sebagai sarana memupuk spiritual akan terus meningkat. Dan hal demikian akan meningkatkan moralitas warga Negara.

Pelaksanaan social finance tersebut, menurut Nicols, Paton, Emerson (2015) bahwa "Common view is that social enterprises are market-based ventures that balance financial success with social purpose but are nonetheless financed by income earned in the private marketplace". ${ }^{91}$ Tujuan dari BMT tidak hanya menyangkut keuntungan finansial melainkan juga bertujuan pada sosial. Pendapatan yang dimiliki, sebagian dialokasikan untuk alokasi sosial. Hal ini memberi dampak bagi masyarakat maupun bagi perusahaan. Gagasan sosial finance juga dimunculkan oleh Mitic dan Rakic, ${ }^{92}$ bahwa social finance dan social banking merupakan upaya keberlangsungan masa depan. Ide dan gagasannya tentang Retail dan Microentrepreneruship, Korporasi Perbankan dan Investasi, Manajemen Aset dan Asuransi, yang memiliki produk dan layanan yang jelas. Social finance menurut Mohamad (2012) (merupakan upaya lembaga keuangan menanamkan nilai ${ }^{93}$ dalam bisnis yang dijalankan.

88 Binti Nur Asiyah, "Source Of Fund Pembiayaan Qardh; Upaya Mewujudkan Keseimbangan Antara Kesejahteraan dan Keadilan Sosial di Perbankan Syariah," Ahkam, 2013.

${ }^{89}$ Lantip Susilowati, "Model Strategi Tumbuh Dan Bertahan Pada Pengelolaan Baitul Maal Wat Tamwil (BMT) Di Kabupaten Tulungagung Dan Ponorogo," IQTISHADIA: Jurnal Ekonomi \& Perbankan Syariah 5, no. 2 (December 28, 2018): 163.

${ }^{90}$ Baznas, Outlook Zakat Indonesia 2018 (Jakarta: Pusat Kajian Strategis Baznas, 2017).

${ }^{91} \mathrm{Alex}$ Nicholls, Rob Paton, and Jed Emerson, Social Finance (Oxford Scholarship Online, 2015).

${ }_{92}^{2}$ Petar Mitic and Slobodan Rakic, Social Finance and Social Banking-a Path towards a More Sustainable Future (Serbia, n.d.).

${ }^{93}$ Saadiah Mohamad, "Is Islamic Finance, Social Finance?," Journal of Emerging Economies and Islamic Research 2, no. 2 (2012): 1-5. 
Nilai itu diharapkan bisa memberikan kontribusi kepada perubahan iklim sosial yang lebih baik. Menurut Weber dan Remer, kehadiran social banking bertujuan untuk bahwa kehadiran tabungan, pembiayaan, investasi dan produk layanan perbankan pada umumnya memberikan dampak positif bagi masyarakat, lingkungan dan budaya. ${ }^{94}$

Menurut Rizzi, Pellegrini, Battaglia (2018) Weber, Duan (2012) menyebutkan "Social Finance (SF) defines the set of alternative lending and investment approaches for financing projects and ventures, requiring to generate both positive impacts on society, the environment, or sustainable development, along with financial return". ${ }^{95}$ Artinya bahwa suatu bisnis tidak hanya berorientasi bisnis, keuntungan, melainkan juga bisnis yang memberikan dampak positif kepada masyarakat, lingkungan maupun filantropy. Social finance menurut Geobey, Westley, Weber (2012) ${ }^{96}$ merupakan terobosan baru dalam pengelolan sosial dalam Islam. Membangun masyarakat melalui keuangan menjadi satu strategi mengajarkan kepada masyarakat agar mampu mengelola perekonomiannya.

BMT sebagai sebuah perusahaan memiliki tujuan bisnis yaitu mendapatkan keuntungan. Keuntungan yang diperoleh akan berdampak pada keberlangsungan bisnis BMT. Perusahaan yang bergerak dalam Perseroan, sudah terdapat aturan tentang Corporate Social Responsibility. ${ }^{97}$ Tanggung jawab sosial dan lingkungan diartikan sebagai "komitmen perseroan untuk berperan serta dalam pembangunan ekonomi berkelanjutan guna meningkatkan kualitas kehidupan dan lingkungan yang bermanfaat, baik bagi perseroan sendiri, komunitas setempat, maupun masyarakat pada umumnya."98

\section{Analisis Peran Social Finance dalam Menumbuhkan Keuangan Inklusif pada BMT Pahlawan Tulungagung dan BMT Podo Joyo Blitar}

Keuangan inklusif pada BMT Pahlawan Tulungagung dan BMT Podo Joyo yang dimaksud adalah akses keuangan bagi anggota secara luas, baik anggota yang bankable maupun yang un-bankable. Keuangan inklusif yang terjadi sebagai kontribusi social finance yang dilakukan oleh kedua BMT memberi peran berupa akses kepada masyarakat untuk menjadi anggota pembiayaan di BMT, sehingga bisa mendapatkan fasilitas pembiayaan Qardh al-hasan guna memenuhi kebutuhan jangka pendeknya. Dari fasilitas pembiayaan ini anggota belum berkesempatan untuk menyisihkan uang untuk menabung karena hanya keterbatasan uang untuk bisa menabung.

\footnotetext{
${ }^{94}$ Olaf Weber and Sven Remer, eds., Social Banks and the Future of Sustainable Finance, 1st ed. (London and New York: Routledge, 2011), 2, accessed July 30, 2019, https://www.taylorfrancis.com/books/9780203827871.

${ }^{95}$ Francesco Rizzi, Chiara Pellegrini, and Massimo Battaglia, "The Structuring of Social Fi Nance: Emerging Approaches for Supporting Environmentally and Socially Impactful Projects," Journal of Cleaner Production 170 (2018): 805-817; 0' Weber and Y. Duan, "Social Finance and Banking. Socially Responsible Finance and Investing: Financial Institutions, Corporations, Investors, and Activists" (2012): 160180.

${ }_{96}^{6}$ Sean Geobey, Frances R Westley, and Olaf Weber, "Enabling Social Innovation through Developmental Social Finance," Journal of Social Entrepreneurship 3, no. 2 (2012): 151-165.

${ }_{97}$ Corporate Social Responsibility diatur dalam Undang-Undang No 40 tahun 2007 tentang Perseroan Terbatas, Peraturan Pemerintah no 47 tahun 2012 tentang tanggung jawab sosial dan lingkungan Perseroan Terbatas.

${ }^{98}$ Undang Undang no 40 tahun 2007 tentang Perseroan Terbatas pasal 1

34
} 
Fasilitas pembiayaan Qardh al-hasan merupakan bagian dari memaksimalkan akses masyarakat miskin pada lembaga microfinance. Menurut Obaidullah and Shirazi, ${ }^{99}$ bahwa potensi islamic social finance antara lain "the primary objective of Islamic social finance zakah, awqaf, cooperative and not for-profit microfinance-is to meet the needs of the poor and to make a dent on their ever-rising levels of poverty". Hal tersebut menegaskan bahwa potensi sosial dalam lembaga keuangan islam antara lain zakat, wakaf, dan lembaga keuangan mikro yang konsen terhadap persoalan non profit yang mempertemukan keperluan masyarakat miskin.

Peran social finance pada BMT dalam menumbuhkan keuangan inklusif berupa kesempatan melakukan pembiayaan ulang atas pembiayaan Qardh al-hasan yang diterima. Berbagai alasan disampaikan yaitu guna meningkatkan modal dan mengembangkan usaha maupun keperluan konsumtif jangka pendek yang mendesak.

Pembiayaan Qardh al-hasan pada Bank Jaiz Nigeria juga merupakan salah satu instrumen untuk meningkatkan peran keuangan inklusif di Nigeria. Sebagaimana paper Yaaba dan Mikailu, ${ }^{100}$ bahwa Bank Sentral Nigeria dalam rangka mengembangkan strategi inklusi keuangan, mengurangi persentasi orang dewasa yang belum tersentuh akses layanan keuangan dan berperan dalam kegiatan ekonomi. Hal yang dilakukan adalah dengan adanya pembiayaan Qardh al-hasan yang tumbuh linier sejajar dari bulan ke bulan, bersamaan dengan pembiayaan lainnya yaitu murabahah, ijarah wa iqtina', istishna. Meski kalau dilihat dari total pembiayaan Qardh al-hasan pada posisi paling kecil yaitu kisaran \$ 8 Milyard, sedangkan murabahah kisaran \$ 75 Milyard. Cornee, Jegers dan Szafarz, ${ }^{101}$ menyebutkan bahwa kontribusi sosial pada keuangan akan terlihat bila ada pengorbanan finansial dari pemilik dana. Artinya bahwa dengan mengalokasikan pembiayaan yang tidak menguntungkan sebesar 8 Milyard, maka bank syariah akan mendapatkan kemanfaatan dan keberkahan pada produk yang lain.

Peran social finance pada BMT dalam menumbuhkan keuangan inklusif berupa kesempatan menjadi anggota BMT dari dana infaq dan sosial bagi anak yatim. Hal ini terjadi di BMT Podo Joyo Blitar, karena karakteristik penyaluran dana sosial yang sebagian dananya berupa dana tunai dan sebagian dalam bentuk rekening, dapat mengenalkan anak untuk menabung. Salah satu anak menyampaikan bahwa menabung terus dilakukan pasca dana bantuan habis karena dimanfaatkan untuk persiapan akhir sekolah. Pada BMT Pahlawan Tulungagung tidak dalam bentuk uang tabungan, sehingga penerima dana tidak memiliki rekening atau tidak memiliki pengalaman memiliki rekening di BMT Pahlawan. Dampak dari pengelolaan dana social finance yang belum memberi kesempatan untuk menabung (atau menjadikan mustahiq menjadi muzakky), menurut Huda sebagaimana akibat dari pengelola yang berlatar belakang pendidikan amil yang professional. ${ }^{102}$ Hal ini berakibat tidak mampu mencari strategi-strategi penerapan yang tepat sesuai dengan kebutuhan dan masa depan BMT.

99 Mohammed Obaidullah and Nasim Shah Shirazi, "Islamic Social Finance Report 1436H (2015)" (2015): 30.

100 Baba N Yaaba and Abubakar Mika'ilu, "Financial Inclusion and Deepening in Nigeria: The Contribution of Jaiz Bank," SHARE Jurnal Ekonomi dan Keuangan Islam 7, no. 2 (2018): 95-115.

${ }^{101}$ Simon Cornée, Marc Jegers, and Ariane Szafarz, "A Theory of Social Finance," Center for Research in Economics and Management (2018): 53.

102 Andi Bahri S., "Zakat Sebagai Instrumen Pembangunan Ekonomi Kesejahteraan Ummat," Li Falah Jurnal Studi Ekonomi dan Bisnis Islam 1, no. 2 (2016).

Iqtishadia: Jurnal Ekonomi dan Perbankan Syariah 
Impementasi dana sosial pada BMT Podo Joyo Blitar sebagian diperuntukkan untuk usaha produktif, sehingga berpotensi untuk melakukan pembiayaan ulang, meskipun dari usaha produktifnya, sebagian anggota belum bisa menabung. Namun demikian anggota melakukan pembiayaan ulang. Pembiayaan ulang pada penerima dana sosial di BMT Podo Joyo dilakukan ditempat yang sama karena BMT telah memberikan stimulan pembiayaan, kemudahan dan akses layanan yang ramah serta kekeluargaan.

Social finance memberikan dampak pada keuangan inklusif, salah satunya adalah zakat. Namun demikian penyaluran zakat belum sesuai dengan mekanisme baznas, dan peruntukkannya belum memperhatikan alokasi asnaf melainkan sesuai pengajuan dari masyarakat. Kondisi ini memberikan efek penyaluran zakat tidak memenuhi persentase alokasi asnaf. Menurut Romdhoni, 103 pendayagunaan zakat produktif memberikan dampak pada peningkatan pendapatan bagi mustahiq sebesar 31\%, sedangkan $69 \%$ dipengaruhi oleh variabel lain. Variabel lain yang perlu dipertimbangkan dalam penyaluran zakat sehingga berdampak pada peningkatan pendapatan bisa menggunakan pendekatan pendampingan bisnis penerima dana zakat, sehingga usaha akan terkontrol dan mengalami peningkatan usaha. Selain itu penyaluran dana tidak dilakukan secara charity karena berpotensi tidak berkembang.

Peran social finance pada BMT dalam menumbuhkan keuangan inklusif berupa kesempatan menjadi anggota funding BMT Podo Joyo dengan menabung dari unsur peneriman dana infaq dan sosial dari unsur janda. Dana yang diterima dari BMT digunakan untuk tambahan modal usaha, dan akhirnya bisa menyisihkan sebagian keuntungannya untuk menabung. Kesempatan para perempuan janda dalam meningkatkan ekonomi melalui akses BMT merupakan bagian untuk memaksimalkan inklusi keuangan dari unsur marginal yaitu wanita. Menurut Akyuwen dan Mangowal, ${ }^{104}$ strategi kedalaman inklusi keuangan pada segmen pemuda, wanita, dan masyarakat pedesaan akan meningkatkan indikator pembangunan Indonesia dibandingkan negara tetangga dalam hal kemiskinan, pengangguran dan rasio gini. Hangl ${ }^{105}$ menyebutkan bahwa kontribusi social finance mampu membebaskan suatu negara dari krisis ekonomi.

Keuangan inklusif merupakan "kondisi setiap anggota masyarakat mempunyai akses terhadap berbagai layanan keuangan formal yang berkualitas secara tepat waktu, lancar, dan aman dengan biaya terjangkau sesuai dengan kebutuhan dan kemampuan dalam rangka meningkatkan kesejahteraan masyarakat". 106 Upaya akses lembaga keuangan formal diawali dengan meningkatkan literasi masyarakat terhadap sistem, produk dan jasa keuangan serta tersedianya layanan layanan keuangan formal yang berkualitas secara tepat waktu, lancar dan aman serta biaya yang terjangkau sesuai kebutuhan dan kemampuan dalam upaya peningkatan kesejahteraan masyarakat.

Upaya menyediakan lembaga keuangan yang mampu diakses oleh masyarakat salah satunya adalah semakin tumbuhnya banks syariah. Bank syariah diharapkan pro terhadap masyarakat miskin yang tidak memiliki kesempatan mengakses layanan perbankan,

\footnotetext{
${ }^{103}$ Romdhoni, "Zakat Dalam Mendorong Pertumbuhan Ekonomi Dan Pengentasan Kemiskinan."

104 Roberto Akyuwen and Caroline Mangowal, "Komparasi Peningkatan Inklusi Keuangan dan Indikator Pembangunan di Indonesia," MODUS 30, no. 1 (96 109AD): 14.

105 Christa Hangl, "A Literature Review About The Landscape of Social Finance," ACRN Journal of Finance and Risk Perspective 3, no. 4 (2014): 64-98.

${ }^{106}$ Lampiran Peraturan Presiden Republik Indonesia Nomor 82 Tahun 2016 Tentang Strategi Nasional Keuangan Inklusif.

36
} 
kurangnya memiliki jaminan serta jaringan yang memadahi sehingga bisa mengakses layanan perbankan. Pilar inklusi keuangan menurut Sanjaya dan Nurschafia adalah

"Di luar jangkauan (outreach), manfaat (usage) dan kualitas (quality) jasa keuangan.

Dimensi outreach penerima mampu menjangkau layanan jasa keuangan. Dimensi

usage mengukur kegunaan sistem keuangan yang tergambar melalui mesin ATM

(Automatic Teller Machine), kantor cabang bank, deposan rumah tangga dan

peminjam. Dimensi quality dalam memenuhi kebutuhan masyarakat."107

Berdasarkan pilar inklusi keuangan tersebut diharapkan mampu meningkatkan kemampuan masyarakat dalam memproduktifkan potensi ekonomi yang dimiliki dari seluruh lapisan masyarakat. Selain pilar inklusi keuangan, pemerintah menetapkan prinsip keuangan inklusif antara lain "kepemimpinan (leadership); keragaman (diversity); inovasi (innovation); perlindungan (protecition; pemberdayaan (empowerment); kerjasama (cooperation); pengetahuan (knowledge); proporsionalitas (proportionality); kerangka kerja (framework)."108

Sembilan prinsip keuangan inklusif di atas diharapkan bisa memunculkan semangat dan kesadaran baik dari lembaga keuangan untuk menyediakan produk sesuai kebutuhan masyarakat, serta masyarakat mampu menangkap produk tersebut sebagai upaya mengembangkan bisnis yang berdampak pada peningkatan pendapatan dan penyerapan tenaga kerja. Masyarakat secara umum mampu bertransaksi pada perbankan syariah, lembaga keuangan mikro syariah seperti hal nya BMT. BMT sebagai lembaga keuangan Syariah non bank melayani akses keuangan pada level mikro. Alam dan Rismi berpendapat bahwa "Perbankan Islam akan dapat berkontribusi dalam mewujudkan keuangan inklusif dengan meningkatkan penggunaan teknologi, model keuangan berbasis ekuitas dan memusatkan perhatian pada keuangan mikro."109 Lembaga keuangan mikro dikenal dekat dengan masyarakat, mengetahui kondisi riil masyarakat sekitar.

Lembaga keuangan mikro bisa dengan mudah dan banyak berada di lingkungan masyarakat desa. Persyaratan mendirikan lembaga keuangan mikro cukup mudah, semisal koperasi syariah, dan dalam hal ini BMT. Pendirian koperasi primer cukup mensyaratkan sekurang-kurangnya dibentuk oleh dua puluh orang. ${ }^{110}$ Kemudahan ini memiliki potensi koperasi akan banyak berada di masyarakat terutama masyarakat desa. Karakteristik masyarakat desa menurut Alam dan Risvi bahwa 80\% hidup dengan pendapatan di bawah $\$ 2$ per hari. Kebanyakan orang miskin tidak memiliki asset tetap dan berharga sehingga tidak mampu memberikan jaminan pada bank komersial saat membutuhkan dana. ${ }^{111}$ Kondisi ini memberikan perhatian bagi lembaga keuangan mikro syariah seperti halnya BMT untuk berperan memberikan peluang keuangan inklusif bagi masyarakat tersebut.

Peningkatan ekonomi akan menciptakan lapangan kerja baru bagi masyarakat, sehingga menurunkan kemiskinan. Dengan demikian jika selama ini potret pertumbuhan ekonomi belum mengekspresikan kesejahteraan masyarakat secara menyeluruh, karena

107 I Made Sanjaya and Nursechafia, "Inklusi Keuangan dan Pertumbuhan Inklusif: Analisis Antar Provinsi di Indonesia," Buletin Ekonomi Moneter dan Perbankan 18, no. 3 (2016): 26.

108 Lampiran Peraturan Presiden Republik Indonesia Nomor 82 Tahun 2016 Tentang Strategi Nasional Keuangan Inklusif.

${ }^{109}$ Nafis Alam and Syed Aun R. Rizvi, eds., Islamic Banking Growth, Stability and Inclusion (Switzerland: Palgrave Macmillan, 2017), 45.

110 Pasal 6, Undang-Undang Nomor 25 Tahun 1992 Tentang Perkoperasian.

${ }^{111}$ Alam and Rizvi, Islamic Banking Growth, Stability and Inclusion, 46. 
akses keuangan mayoritas di miliki oleh menengah ke atas. Maka dengan ini masyarakat akan mampu meningkatkan kesejahteraaanya, sehingga pertumbuhan ekonomi akan merata hingga lapisan ekonomi terendah. Menurut Lujja, "Pinjaman tanpa bunga (qardh al-hasan) didorong untuk menyebarkan inklusi keuangan."112

\section{KESIMPULAN}

Paper ini dapat disimpulkan bahwa: Pertama, Implementasi social finance pada Baitul Maal wat Tamwil di Tulungagung berupa zakat lembaga yang dikeluarkan oleh lembaga rutin tiap bulan sebesar $2,5 \%$ dari pendapatan yang diterima, infaq dari anggota pembiayaan secara suka rela. Implementasi social finance pada BMT Podo Joyo Blitar antara lain: berupa dana sosial yang dikeluarkan dari lembaga setahun sekali sebesar 10 persen dari pendapatan yang diterima, dana infaq dari anggota funding deposito (ditawarkan kepada anggota sehingga tidak merupakan kewajiban) sebesar 2,5\% dari bagi hasil deposito yang didapat anggota, dan dari infaq anggota pembiayaan yang besaran infaq ditawarkan berjenjang mulai dua ribu rupiah sampai dengan sepuluh ribu rupiah. Penyaluran dana social finance pada kedua BMT tersebut dalam bentuk pembiayaan qardh al-hasan, bantuan pendidikan, bantuan yatim, fakir miskin. Yang berbeda dalam penyaluran antara lain untuk BMT Pahlawan Tulungagung memberi alokasi pada pembangunan masjid dan musholla sedangkan pada BMT Podo Joyo Blitar alokasi untuk penerima dari unsur janda.

Kedua, Peran social finance Baitul Maal wat Tamwil Pahlawan Tulungagung dalam menumbuhkan keuangan inklusif antara lain dalam bentuk pembiayaan qardh al-hasan. Bantuan lainnya bersifat langsung, sehingga tidak berdampak pada kesempatan menabung. Sedangkan pada BMT Podo Joyo Blitar peran social finance dalam menumbuhkan keuangan inklusif antara lain dalam bentuk pembiayaan Qardh al-hasan, bantuan untuk yatim dalam bentuk akun tabungan, dan dampak dari bantuan dari unsur janda memberikan kesempatan bagi anggota untuk menabung di BMT.

\section{DAFTAR PUSTAKA}

Akyuwen, Roberto, and Caroline Mangowal. "Komparasi Peningkatan Inklusi Keuangan Dan Indikator Pembangunan Di Indonesia." MODUS 30, no. 1 (n.d.): 96-109.

- - . "Komparasi Peningkatan Inklusi Keuangan dan Indikator Pembangunan di Indonesia." MODUS 30, no. 1 (96 109AD): 14.

Alam, Nafis, and Syed Aun R. Rizvi, eds. Islamic Banking Growth, Stability and Inclusion. Switzerland: Palgrave Macmillan, 2017.

Ascarya. Micro Level Models of Integrated Islamic Commercial and Social Finance in Indonesia, 2018.

Aziz bin Baz, Syaikh Abdul. Zakat. Translated by Ummu Abdillah al-Buthoniyah, 2009. http://www.raudhatulmuhibbin.org.

Azizah, Rana Ayu, and Noven Suprayogi. "Analisis Keoptimalan Fungsi Baitul Maal Pada Lembaga Keuangan Mikro Islam." JESTT 1, no. 12 (2014): 841-852.

Bahri S., Andi. "Zakat Sebagai Instrumen Pembangunan Ekonomi Kesejahteraan Ummat." Li Falah Jurnal Studi Ekonomi dan Bisnis Islam 1, no. 2 (2016).

112 Sulaiman Lujja et al., "The Feasibility of Adopting Islamic Banking System under the Existing Laws in Uganda," International Journal of Islamic and Middle Eastern Finance and Management 9, no. 3 (2016): 417-434.

38 
Bank Indonesia. Pengelolaan Zakat Yang Efektif: Konsep Dan Praktik Di Berbagai Negara. Jakarta: Bank Indonesia dan UII, 2016.

- - W Wakaf: Pengaturan Dan Tata Kelola Yang Efektif. Jakarta: Bank Indonesia dan Universitas Airlanggga, 2016.

Bashori, M Anwar. Mendorong Pengembangan Islamic Social Finance Dalam Rangkat Mewujudkan Masyarakat Sejahtera. Bank Indonesia. Indonesia, 2017.

Bayinah, Ai Nur. "Role of Zakat as Social Finance Catalyst to Islamic Banking and Economic Growth." International Journal of Zakat 2, no. 2 (2017): 55-70.

Baznas. Outlook Zakat Indonesia 2018. Jakarta: Pusat Kajian Strategis Baznas, 2017.

Cornée, Simon, Marc Jegers, and Ariane Szafarz. "A Theory of Social Finance." Center for Research in Economics and Management (2018): 53.

Dakhoir, Ahmad. "Reactualization of The Islamic Social Finance System of Saprah Amal in Banjar Community Indonesia." Journal of Legal, Ethical and Regulatory System 21, no. 4 (2018): 1-5.

Damanhur, and Nurainiah. "Analisis Pengaruh Bantuan Zakat Terhadap Tingkat Kesejahteraan Masyarakat Kabupaten Aceh Utara." Jurnal Visioner \& Strategis 5, no. 2 (2016): 71-82.

Fadlan, Fadlan. "KONSEP PEMBANGUNAN EKONOMI BERBASIS ISLAM (Sebuah Upaya Pembangunan Ekonomi Indonesia yang Adil, Makmur, dan Sejahtera)." Al-Ihkam: Jurnal Hukum \& Pranata Sosial 5, no. 2 (2012): 257-274.

Geobey, Sean, Frances R Westley, and Olaf Weber. "Enabling Social Innovation through Developmental Social Finance." Journal of Social Entrepreneurship 3, no. 2 (2012): $151-165$.

Gurning, Herfita Rizki Hasanah, and Haroni Doli Hamoraon Ritonga. "Analisis Tingkat Kesadaran Masyarakat Kecamatan Medan Baru Dalam Membayar Zakat." Jurnal Ekonomi da Keuangan 3, no. 7 (n.d.).

Hangl, Christa. "A Literature Review About The Landscape of Social Finance." ACRN Journal of Finance and Risk Perspective 3, no. 4 (2014): 64-98.

Harji, Karim, and Tessa Hebb. "Impact Investing for Social Finance." ANSER Conference (2010): 1-20.

Jones, John. "Social Finance: Commerce and Community in Developing Countries." International Journal of Social Economics 37, no. 6 (2010): 415-426.

Lubis, Fauzi Arif. "Peranan BMT Dalam Pemberdayaan Ekonomi Nasabah Di Kecamatan Berastagi-Kabanjahe Kabupaten Karo ( Studi Kasus Bmt Mitra Simalem Al-Karomah )." Human Falah 3, no. 2 (2016): 271-295.

Lujja, Sulaiman, Mustafa Omar Mohammad, Rusni Bt. Hassan, and Umar A. Oseni. "The Feasibility of Adopting Islamic Banking System under the Existing Laws in Uganda." International Journal of Islamic and Middle Eastern Finance and Management 9, no. 3 (2016): 417-434.

Martowardojo, Agus D.W. "Integrating Islamic Commercial and Social Finance to Strengthen Financial System Stability." International Seminar and the 2nd JIMD (2016): 1-8.

Meutia, I. Shari"ah Enterprise Theory Sebagai Dasar Pengungkapan Tanggungjawab Sosial Bank Syariah. Universitas Brawijaya Malang, 2009.

Mitic, Petar, and Slobodan Rakic. Social Finance and Social Banking- a Path towards a More Sustainable Future. Serbia, n.d.

Mohamad, Saadiah. "Is Islamic Finance, Social Finance ?" Journal of Emerging Economies and Islamic Research 2, no. 2 (2012): 1-5. 
Nengsih, Novia. "Peran Perbankan Syariah Dalam Mengimplementasikan Keuangan Inklusif Di Indonesia." Etikonomi 14, no. 2 (2015): 221-240.

Nicholls, Alex, Rob Paton, and Jed Emerson. Social Finance. Oxford Scholarship Online, 2015.

Nofrianto, and Suardi. "Bank Syariah Dan Pemberdayaan Coorporate Social Responsibility: Peran Dan Fungsi Bank Syariah Perspektif Filosofi Sosio - Ekonomi." Akademika 20, no. 02 (2015): 261-276.

Novarela, Dori, and Indah Mulia Sari. "Pelaporan Corporate Social Responsibility Perbankan Syariah Dalam Perspektif Syariah Enterprise Theory." Jurnal Akuntansi dan Keuangan Islam 2, no. 2 (2015): 145-160.

Nugroho, Ari, and Evi Yulia Purwanti. Determinan Inklusi Keuangan Di Indonesia. Semarang, 2014.

Nurhasanah, Siti. "Akuntabilitas Laporan Keuangan Lembaga Amil Zakat Dalam Memaksimalkan Potensi Zakat." Jurnal Ilmu Akuntansi 11, no. 2 (2018).

Obaidullah, Mohammed, and Nasim Shah Shirazi. "Islamic Social Finance Report 1436H (2015)" (2015): 164.

Othman, Rohana, Azlan Md Thani, and Erlane K Ghani. "Determinants Of Islamic Social Reporting Among Top Shariah -Approved Companies In Bursa Malaysia." Research Journal of International Studies 12, no. 12 (2009): 4-20.

Prastowo. "Analisis Regional Keuangan Inklusi Perbankan Syariah Terhadap Ketimpangan Pendapatan Di Indonesia." Jurnal Ekonomi \& Keuangan Islam 4, no. 1 (2018): 51-57.

Ridlo, Ali. "Zakat Dalam Perspektif Ekonomi Islam." Jurnal Al - 'Adl 7, no. 1 (2014): 19.

Rizzi, Francesco, Chiara Pellegrini, and Massimo Battaglia. "The Structuring of Social Fi Nance : Emerging Approaches for Supporting Environmentally and Socially Impactful Projects." Journal of Cleaner Production 170 (2018): 805-817.

Romdhoni, Abdul Haris. "Zakat Dalam Mendorong Pertumbuhan Ekonomi Dan Pengentasan Kemiskinan." Jurnal Ilmiah Ekonomi Islam 03, no. 01 (2017): 41-51.

Sanjaya, I Made, and Nursechafia. "Inklusi Keuangan dan Pertumbuhan Inklusif: Analisis Antar Provinsi di Indonesia." Buletin Ekonomi Moneter dan Perbankan 18, no. 3 (2016): 26.

- - " "Inklusi Keuangan Dan Pertumbuhan Inklusif: Analisis Antar Provinsi Di Indonesia." Buletin Ekonomi Moneter dan Perbankan 18, no. 3 (2016): 281-306.

Susilowati, Lantip. "Model Strategi Tumbuh Dan Bertahan Pada Pengelolaan Baitul Maal Wat Tamwil (BMT) Di Kabupaten Tulungagung Dan Ponorogo." IQTISHADIA: Jurnal Ekonomi \& Perbankan Syariah 5, no. 2 (December 28, 2018): 163.

Tim Penyusun Direktorat Pemberdayaan Zakat. Zakat Community Development; Model Pengembangan Zakat. Direktorat Jenderal Bimbingan Masyarakat Islam, Direktorat Pemberdayaan Zakat, 2013.

Weber, O', and Y. Duan. "Social Finance and Banking. Socially Responsible Finance and Investing: Financial Institutions, Corporations, Investors, and Activists" (2012): 160 180.

Weber, Olaf, and Sven Remer, eds. Social Banks and the Future of Sustainable Finance. 1st ed. London and New York: Routledge, 2011. Accessed July 30, 2019. https://www.taylorfrancis.com/books/9780203827871.

Yaaba, Baba N, and Abubakar Mika'ilu. "Financial Inclusion and Deepening in Nigeria: The Contribution of Jaiz Bank." SHARE Jurnal Ekonomi dan Keuangan Islam 7, no. 2 (2018): 95-115.

PERATURAN PERUNDANG-UNDANGAN 
Fatwa Dewan Syariah Nasional Nomor 19/DSN-MUI/IV/2001 tentang al-Qardh

Lampiran Peraturan Presiden Republik Indonesia Nomor 82 Tahun 2016 Tentang Strategi Nasional Keuangan Inklusif

Undang-Undang Nomor 23 Tahun 2011, Tentang Pengelolaan Zakat

Undang-Undang Nomor 40 Tahun 2007 Tentang Perseroan Terbatas. 